\title{
HUBUNGAN KONDISI SOSIAL EKONOMI PEMILIK UMKM DENGAN PERSEPSI TERHADAP KARAKTERISTIK SOCIOPRENEUR
}

\section{Relationship between the Social and Economic Conditions of MSME Owners with Perceptions of Sociopreneur Characteristics}

\author{
Rizqiah Khalida*) dan Sofyan Sjaf \\ Departemen Sains Komunikasi dan Pengembangan Masyarakat, Fakultas Ekologi Manusia, Institut \\ Pertanian Bogor, Dramaga Bogor 16680, Indonesia \\ *)E-mail: rizqiah_khalida@apps.ipb.ac.id
}

Diterima: 23-08-2021 | Disetujui: 17-10-2021 | Publikasi online: xx-10-2021

\begin{abstract}
Social entrepreneurs are individuals who have entrepreneurial characteristics and are able to identify and solve social problems. One of them is by developing Micro, Small and Medium Enterprises (MSMEs) in rural areas. The perception of MSME owners is very important in influencing the response to the effortd of the sociopreneur. Perception cannot be separated from the influencing factors. These factors include socioeconomic condition consistingof education level, income level, own means of transportation, and social interaction patterns. The perceptions observed included the aspects of creation of social values, social entrepreneurship, social entrepreneurial organizations, and market orientation. This study uses a quantitative approach that is supported by qualitative data with 33 respondents. The purpose of this study was to analyze the socio-economic conditions of MSME owners and how their perceptions of sociopreneur characteristics. The results obtained indicate that there is an insignificant relationship between the socioeconomic conditions of MSME owners with the perception of sociopreneur characteristics.
\end{abstract}

Keywords: Perceptions, socio-economic conditions, sociopreneur characteristics

\begin{abstract}
ABSTRAK
Wirausaha sosial merupakan individu yang mempunyai karakter kewirausahaan dan mampu mengidentifikasi serta memecahkan persoalan sosial. Salah satu caranya yaitu dengan mengembangkan Usaha Mikro, Kecil, dan Mengengah (UMKM) di pedesaan. Persepsi pemilik UMKM sangat penting dalam mempengaruhi respon terhadap usaha-usaha yang dilakukan sociopreneur. Persepsi itu sendiri tidak lepas dari faktor-faktor yang mempengaruhi. Faktor tersebut antara lain faktor kondisi sosial ekonomi yang terdiri dari tingkat pendidikan, tingkat pendapatan, kepemilikan alat transportasi, dan pola interaksi sosial. Persepsi yang diamati meliputi aspek menciptakan nilai sosial, wirausaha sosial, organisasi kewirausahaan sosial, dan orientasi pasar. Penelitian ini menggunakan metode kuantitatif yang didukung oleh data kualitatif dengan responden sebanyak 33 orang. Tujuan penelitian ini adalah menganalisis kondisi sosial ekonomi pemilik UMKM dan bagaimana persepsinya terhadap karakteristik sociopreneur. Hasil penelitian yang diperoleh menunjukkan bahwa terdapat hubungan yang tidak signifikan antara kondisi sosial ekonomi pemilik UMKM dengan persepsi terhadap karakteristik sociopreneur.
\end{abstract}

Kata kunci: Karakteristik sociopreneur, kondisi sosial ekonomi, persepsi 


\section{PENDAHULUAN}

Keterbelakangan bangsa Indonesia tidak lepas dari desa-desa dan masyarakat yang ada di dalamnya. Tidak sedikit permasalahan tentang pengangguran dan kemiskinan kita temukan di pedesaan. Padahal sumber daya alam yang paling kaya biasanya terdapat di desa. Menurut Haholongan (2016) kemiskinan dan pengangguran di Indonesia merupakan suatu permasalahan dari sejak dulu yang sulit diatasi. Upaya pemerintah untuk menanggulangi kemiskinan dan pengangguran ini dilakukan dengan berbagai cara, salah satunya dengan membuat bermacammacam program, seperti program penyaluran Kredit Usaha Rakyat (KUR), Tabungan Keluarga Sejahtera (TAKESRA), dan Kredit Keluarga Sejahtera (KUKESRA). Namun program-program yang dibuat pemerintah relatif belum berhasil menekan angka kemiskinan dan pengangguran di Indonesia yang hingga saat ini masih tergolong cukup tinggi. Jumlah penduduk miskin (penduduk dengan pengeluaran per kapita per bulan di bawah Garis Kemiskinan) di Indonesia mencapai 25,67 juta orang (BPS 2018)1.

Chambers dalam Sjaf (2019) menekankan orientasi pembangunan yang dilakukan di desa yang identik dengan proyek-proyek pembangunan perlu dievaluasi secara terus-menerus dan bagaimana melihat keterbelakangan dari segi material dan sosial. Selanjutnya Chambers mengingatkan bahwa proyek-proyek pembangunan di desa yang dilakukan oleh mereka (negaranegara maju, pemerintah, LSM, peneliti, dan lain-lainnya) adalah "orang luar", sedangkan masyarakat desa itu sendiri adalah "orang dalam". Kemudian Sjaf (2019) menuturkan bahwa dalam proses pembangunan di desa, "orang luar" sering kali hanya melakukan "wisata pembangunan desa" sehingga proyek-proyek pembangunan tidak dapat memecahkan permasalahan substantif yang dialami "orang dalam". Selain itu, terdapat budaya yang dimiliki "orang luar" terhadap pembangunan desa. Budaya yang dimaksud, adalah (1) budaya kaum intelektual yang identik dengan sikap kritis dan pemahaman terhadap pembangunan desa; dan (2) budaya pelaksana pembangunan desa, seperti: pemerintah pusat maupun daerah, para peneliti, dan petugas badan-badan sosial. Mereka ini identik dengan mencari hal yang akan berjalan dengan benar. Dari kedua budaya ini, menurut Chambers untuk melihat kemiskinan yang terjadi selama ini di desa maka perlu juga memahami budaya ketiga, yaitu budaya "orang dalam" (warga desa) sebagai pusat dan perhatian serta tempat para ilmuan dan pelaksana untuk belajar. Oleh karena itu, "orang luar" harus memliki pemahaman yang lebih baik tentang kemiskinan di desa dan menentukan apa yang sebaiknya dilakukan untuk mengentaskan kemiskinan di desa.

Menurut Masturin (2015) kemandirian ekonomi adalah salah satu jawaban untuk menghadapi kompetisi di era global sehingga masyarakat mampu keluar dari kemiskinan dan keterbelakangan. Era global bagi negara berkembang artinya harus bekerja keras dan cerdas untuk berkompetisi dengan sumber daya manusia dari negara-negara maju. Peluang kerja yang terbatas menuntut sumber daya lokal agar memiliki kemampuan dalam membuka lapangan kerja sendiri dengan mengolah sumber daya yang ada melalui inovasi dan perbaikan-perbaikan yang bersifat kontinyu (continuin improvement). Untuk mendukung proses kemandirian ini hendaknya pembangunan diarahkan pada bentuk-bentuk yang memberikan daya dukung bagi keseimbangan antara perkotaan dan pedesaan. Lingkungan pedesaan dengan sejumlah karakteristik unik seperti sifat kekeluargaan dan kegotongroyongan merupakan daya tarik yang dapat dioptimalkan melalui kegiatan yang memberikan kontribusi bagi peningkatan kesejahteraan sehingga desa tidak lagi ditinggalkan oleh penghuninya. Namun demikian, terdapat beberapa kendala dalam membuka peluang kerja dipedesaan seperti keterbatasan kapabilitas finansial, keterbatasan kemampuan manajemen, terbatasnya jaringan (networking), dan lemahnya perhatian pemerintah.

1 Badan Pusat Statistik. 2019. Profil Kemiskinan di Indonesia September 2018. 
Kemudian, Masturin (2015) menjelaskan lebih lanjut bahwa sociopreneur merupakan salah satu pendekatan yang dapat diimplementasikan untuk pemberdayaan modal sosial pedesaan yang mampu memecahkan masalah-masalah sosial dengan menggunakan prinsip-prinsip kewirausahaan (entrepreneurial) untuk mengorganisir, menciptakan, dan mengelola sebuah usaha agar tercapai tujuan sosial. Entrepreneurship selama ini sangat identik dengan bisnis dan dikelola dengan tujuan untuk mencapai keuntungan semata, maka sociopreneurship memiliki tujuan yang lebih bernilai yaitu menciptakan modal sosial yang tangguh dan berdaya saing. Pendekatan sociopreneur tidak hanya menggunakan modal fisik (physical capital) tetapi juga dengan mengoptimalkan modal intelektual dan emosional. Salah satu tugas sociopreneur adalah meningkatkan motivasi dan semangat masyarakat agar memiliki kemauan keluar dari masalah yang dihadapinya dengan mengandalkan potensi dirinya.

Munculnya secara terus menerus permasalahan sosial yang belum secara tuntas diselesaikan oleh pemerintah membuat masyarakat mencoba melakukan langkah aktif dan strategis melalui aktivitas bisnis untuk memecahkan masalah-masalah sosial. Menurut Suyatna dan Nurhasanah (2017) berbagai macam agenda publik banyak yang sudah menyentuh aktivitas sociopreneur sebagai topik yang menarik. Hal ini tidak lepas dari cakupan kegiatan sociopreneur yang luas dan beririsan dengan berbagai bidang lainnya. Tujuan pendekatan sociopreneur ini dalam kegiatan pengabdian untuk mendorong anggota masyarakat agar bangkit dengan kesadarannya sendiri untuk memajukan desanya. Kemiskinan karena sempitnya lapangan pekerjaan dan kurangnya keterampilan dapat dihilangkan melalui tumbuhnya kesadaran untuk maju dan berkembang dengan menggali potensi diri dan melakukan upaya-upaya peningkatan kompetensi secara produktif.

Putri (2017) sociopreneur merupakan solusi gerakan sosial di bidang ekonomi yang dapat memberikan peluang usaha terutama di daerah pedesaan. Selain perbaikan ekonomi mikro, sociopreneur mampu meningkatkan perekonomian nasional. Disinilah alasan mengapa sociopreneur mampu menjadi solusi, karena selain bersifat sustainable pada perekonomian, sociopreneur mampu memberikan solusi efektif dan taktis terhadap permasalahan perekonomian Indonesia.

Disimpulkan bahwa sociopreneur merupakan salah satu pendekatan yang dapat diimplementasikan untuk pemberdayaan modal sosial pedesaan yang mampu memecahkan masalah-masalah sosial dengan menggunakan karakteristik sociopreneur.

Konsep-konsep Usaha Mikro, Kecil, dan Menengah (UMKM) ataupun ekonomi kreatif merupakan kerangka besar yang selalu berkorelasi dengan aktivitas sociopreneur. Dari sudut pandang pemerintah menurut Suyatna dan Nurhasanah (2017) kehadiran sociopreneur saat ini sudah dianggap sebagai sebuah profesi yang tak hanya dilirik dari segi outputnya saja, tetapi pula dari sisi prosesnya. Hingga saat ini belum ada aturan atau regulasi jelas tentang aktivisme sociopreneur. Hanya saja beberapa kementerian ada yang memasukan program-program sociopreneurship, misalnya Kementerian Koperasi dan UMKM (Usaha Mikro, Kecil, dan Menengah), Kementerian Pemuda dan Olahraga, serta Badan Ekonomi Kreatif (Bekraf). Sejauh ini kesepakatan umum yang berada pada tataran masyarakat menjadi landasan hukum secara informal yang dapat menggerakkan berbagai elemen di masyarakat untuk tergerak pada bisnis sosial. Berdasarkan UU Tentang $\mathrm{UMKM}^{2}$ pada Pasal 5 dijelaskan mengenai tujuan pemberdayaan Usaha Mikro, Kecil, dan Menengah meliputi: (a) Mewujudkan struktur perekonomian nasional yang seimbang, berkembang, dan berkeadilan; (b) Menumbuhkan dan mengembangkan kemampuan Usaha Mikro, Kecil, dan Menengah menjadi usaha yang tangguh dan mandiri; dan (c) Meningkatkan peran Usaha Mikro, Kecil, dan Menengah dalam pembangunan daerah, penciptaan lapangan kerja, pemerataan pendapatan, pertumbuhan ekonomi, dan pengentasan rakyat dari kemiskinan.

2 Undang-Undang Republik Indonesia No 20 Tahun 2008 Tentang Usaha Mikro, Kecil, dan Menengah. 
Hartono dan Hartomo (2014) menjelaskan masalah yang masih krusial dihadapi oleh UMKM diantaranya adalah masih rendahnya permodalan. UMKM masih menghadapi kendala dalam menambah permodalan, baik untuk modal kerja maupun modal investasi. Kesulitan dalam masalah permodalan membawa ke masalah mendasar yang mempengaruhi proses inovasi dan transformasi UMKM, mengimbas pula pada kesulitan dalam pemasaran terutama dari segi pengenalan pasar, penentuan harga, negosiasi, serta jalur distribusi dan penjualan (Arsyad 2003). Selain itu pengusaha kecil pada umumnya tidak dapat mempromosikan produknya melalui media massa, karena volume pendapatan produksi yang tidak mampu menutup biaya promosi (Trisanti 2001).

Kemudian Hartono dan Hartomo (2014) menjelaskan lebih lanjut berbagai kendala lainnya yang masih sering ditemui pada UMKM adalah masih rendahnya kualitas SDM, yang tercermin dari kurang berkembangnya perilaku kewirausahaan, lemahnya kaderisasi, kreativitas, disiplin, etos kerja, dan profesionalisme. Berbagai kendala tersebut menyebabkan sangat rentannya UMKM dalam menghadapi persaingan. Pengalaman menunjukkan bahwa eksistensi UMKM yang terancam bahkan mati sebelum bersentuhan dengan iklim liberisasi perdagangan dunia.

Upaya seorang sociopreneur dalam menanggulangi permasalahan yang dihadapi UMKM adalah dengan melakukan beberapa cara. Ada hal penting yang dinisiasikan seorang sociopreneur dalam mengelola UMKM, yaitu memberikan bantuan modal usaha ketika UMKM membutuhkan, mendampingi dari sisi produk supaya memiliki standarisasi yang baik, mendampingi dari sisi pasar dengan mengenalkan pemasaran secara offline dan juga online, dan memberikan inovasi. Berdasarkan hal tersebut, karakteristik sociopreneur merupakan salah satu faktor yang mempengaruhi keberhasilan dari berkembangnya UMKM di suatu desa. Diperlukan analisis mengenai karakteristik sociopreneur dalam program pengembangan UMKM serta kondisi kehidupan pemilik UMKM setelah adanya sociopreneur tersebut. Oleh karena itu, maka persepsi dan respon pemilik UMKM juga sangat diperlukan guna mengetahui sejauh mana program ini dapat diterima dan dilaksanakan oleh pemilik UMKM.

Persepsi merupakan cara pandang seseorang terhadap suatu objek dengan mempertimbangkan segala aspek yang berkaitan dengan dirinya dan lingkungannya. Ada beberapa faktor yang mempengaruhi persepsi seseorang terhadap suatu pengembangan UMKM di Desa Tegalwaru. Faktor tersebut antara lain kondisi sosial ekonomi masyarakat desa sebagai pemilik UMKM yang meliputi tingkat pendapatan, tingkat pendidikan, kepemilikan alat transportasi, dan pola interaksi sosial. Sedangkan bentuk persepsi terhadap pengembangan UMKM yang dilakukan oleh sociopreneur meliputi karkateristik sociopreneur yang terdapat di dalam program pengembangan UMKM tersebut. Antara lain persepsi pemilik UMKM mengenai karakteristik sociopreneur dalam menciptakan nilai sosial, wirausaha sosial, organisasi kewirausahaan sosial, dan orientasi pasar. Persepsi tersebut mampu mempengaruhi respon pemilik UMKM secara positif maupun negatif terhadap usaha-usaha yang dilakukan sociopreneur. Respon pemilik UMKM inilah yang nantinya dapat menjadi masukan bagi keberhasilan pengembangan UMKM berikutnya.

Berdasarkan kaitan pentingnya karakteristik sociopreneur dalam program pengembangan UMKM, maka hal tersebut menjadi pertanyaan utama dalam penelitian, yakni bagaimana respon pemilik Usaha Mikro Kecil dan Menengah (UMKM) terhadap usaha-usaha yang dilakukan sociopreneur dalam mengembangkan UMKM.

Berangkat dari uraian diatas, penelitian ini bertujuan (1) menganalisis kondisi sosial ekonomi pemilik UMKM; (2) menganasilis persepsi pemilik UMKM terhadap karakteristik sociopreneur; dan (3) menganalisis hubungan antara kondisi sosial ekonomi pemilik UMKM dengan persepsi terhadap karakteristik sociopreneur. 


\section{PENDEKATAN TEORITIS}

\section{Usaha Mikro Kecil dan Menengah}

Menurut Sarfiah et al. (2019) Usaha Mikro, Kecil, dan Menengah (UMKM) memiliki definisi yang berbeda pada setiap literatur menurut beberapa instansi atau lembaga bahkan undangundang. Sesuai dengan Undang-Undang Nomor 20 tahun 2008 tentang Usaha Mikro, Kecil, dan Menengah (UMKM), UMKM didefinisikan sebagai berikut: (1) Usaha mikro adalah usaha produktif milik orang perorangan dan/atau badan usaha perorangan yang memenuhi kriteria Usaha Mikro sebagaimana diatur dalam Undang-Undang ini; (2) Usaha Kecil adalah usaha ekonomi produktif yang berdiri sendiri, yang dilakukan oleh orang perorangan atau badan usaha yang bukan merupakan anak perusahaan atau bukan cabang perusahaan yang dimiliki, dikuasai, atau menjadi bagian baik langsung maupun tidak langsung dari Usaha Menengah atau Usaha Besar yang memenuhi kriteria Usaha Kecil sebagaimana dimaksud dalam UndangUndang ini; dan (3) Usaha Menengah adalah usaha ekonomi produktif yang berdiri sendiri, yang dilakukan oleh orang perorangan atau badan usaha yang bukan merupakan anak perusahaan atau cabang perusahaan yang dimiliki, dikuasai, ataupun menjadi bagian baik langsung maupun tidak langsung dengan Usaha Kecil atau Usaha Besar dengan jumlah kekayaan bersih atau hasil penjualan tahunan sebagaimana diatur dalam Undangundang ini.

\section{Kondisi Sosial Ekonomi}

Menurut Lontoh (2016) sosial mengandung arti segala sesuatu yang berhubungan dengan masyarakat, sementara itu ekonomi memiliki artian sebagai ilmu yang berhubungan dengan asas produksi, distribusi, pemakaian barang serta kekayaan. Sekilas sosial dan ekonomi seperti dua hal dan cabang ilmu yang berbeda, namun diantara keduanya sebenarnya terdapat kaitan yang erat. Salah satu kaitan yang erat tersebut adalah jika keperluan ekonomi tidak terpenuhi maka akan terdapat dampak sosial yang terjadi di masyarakat. Jadi bisa disimpulkan bahwa sosial ekonomi mengandung pengertian sebagai segala sesuatu hal yang berhubungan dengan tindakan ekonomi dalam pemenuhan kebutuhan masyarakat seperti sandang, pangan dan papan.

Mengenai kondisi sosial ekonomi, menurut Soekanto dalam Arifin (2002), menjelaskan kondisi sosial ekonomi sebagai kaitan antara status sosial dan kebiasaa hidup sehari-hari yang telah membudaya bagi individu atau kelompok di mana kebiasaan hidup yang membudaya ini biasanya disebut dengan culture activity, kemudian ia juga menjelaskan pula bahwa dalam semua masyarakat di dunia baik yang sederhana maupun yang kompleks, pola interaksi atau pergaulan hidup antara individu menunjuk pada perbedaan kedudukan dan derajat atau status kriteria dalam membedakan status pada masyarakat yang kecil biasanya sangat sederhana, karena di samping jumlah warganya yang relatif sedikit, juga orang-orang semua yang dianggap tinggi statusnya tidak begitu banyak jumlah maupun ragamnya.

Menurut Bahrowi dan Juariyah (2010) kondisi sosial ekonomi adalah posisi individu dan kelompok yang berkenaan dengan ukuran rata-rata yang berlaku umum tentang pendidikan, pemilikan barang-barang, dan partisipasi dalam aktivitas kelompok dari komunitasnya, sedangkan kondisi sosial ekonomi kaitannya dengan status sosial ekonomi itu sendiri dengan kebiasaan hidup sehari-hari individu atau kelompok.

Menurut Ria (2017) Kondisi sosial ekonomi merupakan suatu usaha dari masyarakat untuk menanggulangi atau mengurangi kesulitan hidup serta dalam memenuhi kebutuhan hidup dengan menggunakan beberapa parameter untuk kondisi sosial ekonomi, antara lain: usia, jenis kelamin, mata pencaharian, pendidikan, kesehatan, dan pendapatan. Faktor-faktor tersebut pada akhirnya akan mempengaruhi tingkat kesejahteraan. Jadi kondisi sosial ekonomi masyarakat merupakan segala sesuatu yang berkenaan dengan masyarakat terutama dalam kaitannya untuk mencapai kesejahteraan dengan cara memanfaatkan tenaga, waktu, dan sebagainya. 
Kondisi sosial ekonomi meliputi tingkat pendidikan, tingkat pendapatan, kepemilikan, dan pola interaksi sosial. Adapun secara umum kondisi sosial ekonomi tersebut dijelaskan sebagai berikut.

\section{a) Tingkat pendapatan}

Menurut Sukirno (2011) pendapatan adalah jumlah penghasilan yang diterima oleh penduduk atas prestasi kerjanya selama satu periode tertentu, baik harian, mingguan, bulanan ataupun tahunan. Sedangkan menurut Sukmawati (2013) pendapatan adalah jumlah keseluruhan dari hasil yang diperoleh baik dari pekerjaan pokok maupun pekerjaan sampingan yang dapat dilihat dan diukur dengan rupiah dalam waktu tertentu. Menurut Surat Edaran Gubernur Jawa Barat Nomor 561/75/Yanbangsos Tanggal 21 November 2019 Tentang Pelaksanaan Upah Minimum Kabupaten/Kota di Daerah Provinsi Jawa Barat Tahun 2020, Kabupaten Bogor tercantum sebesar Rp.4.083.670,00.

\section{b) Tingkat Pendidikan}

Pendidikan memegang peranan penting dalam membentuk dan menciptakan masyarakat sesuai yang diharapkan, karena pendidikan berfungsi untuk mengembangkan wawasan dan meningkatkan kualitas manusia terhadap agama, ekonomi, sosial sehingga dapat membawa masyarakat untuk mencapai tujuan pembangunan nasional (Erista, 2014).

Menurut Winarsih (2018) pendidikan diupayakan untuk mewujudkan individu agar dapat mengembangkan potensi dirinya dengan bekal memiliki kekuatan spiritual keagamaan, pengendalian diri, kepribadian, kecerdasan, akhlak mulia, serta keterampilan yang diperlukan dirinya, masyarakat, bangsa dan negara. Pendidikan adalah aktifitas dan usaha untukmeningkatkan kepribadian dengan jalan membina potensi-potensi pribadinya, yaitu rohani (fikiran, cipta, rasa, dan hati nurani) serta jasmani (panca indera dan keterampilan-keterampilan). Berdasarkan penyelenggaraannya, pendidikan dibedakan menjadi pendidikan formal yang dapat diperoleh dari sekolah, pendidikan nonformal yang dapat diperoleh dari lingkungan masyarakat atau bimbingan belajar, dan pendidikan informal yang diperoleh dari lingkungan keluarga.

Berdasarkan tingkat pendidikan, UU No. 20 tahun 2003 menggolongkan dalam tiga bagian yaitu rendah, menengah dan tinggi: (1) Pendidikan dasar yaitu pendidikan yang melandasi jenjang pendidikan menengah. Pendidikan dasar berbentuk Sekolah Dasar (SD) dan Madrasah Ibtidaiyah (MI) atau bentuk lain yang sederajat serta Sekolah Menengah Pertama (SMP) dan Madrasah Tsanawiyah (MTs), atau bentuk lain yang sederajat; (2) Pendidikan Menengah merupakan pendidikan lanjutan dari pendidikan dasar. Pendidikan menengah berbentuk Sekolah Menengah Atas (SMA), Madrasah Aliyah (MA), Sekolah Menengah Kejuruan (SMK) dan Madrasah Aliyah Kejuruan (MAK) atau bentuk lain yang sederajat; dan (3) Pendidikan tinggi merupakan jenjang pendidikan setelah pendidikan menengah yang mencakup program pendidikan diploma, sarjana, magister, spesialis dan doktor yang diselenggarakan oleh perguruan tinggi. Perguruan tinggi dapat berbentuk akademi, politeknik, sekolah tinggi, institut atau universitas.

\section{c) Kepemilikan}

Pemilikan kekayaan atau fasilitas adalah kekayaan dalam bentuk barang yang masih bermanfaat dalam menunjang ekonomi. Pemilikan kekayaan yang bernilai ekonomis dalam berbagai bentuk dan ukuran seperti perhiasan, barang-barang elektronik, dan lain-lain dapat menunjukkan adanya pelapisan dalam masyarakat (Abdulsyani 1994 dalam Garini 2017). Ukuran kekayaan merupakan harta benda atau materi yang dimiliki seseorang.Ukuran kekayaan tersebut dapat dilihat dari bentuk dan luas rumah yang bersangkutan, luas kepemilikan tanah, kepemilikan barang berharga dan fasilitas yang dimiliki. Pemilikan barang-barang yang berhargapun dapat digunakan untuk 
ukuran sosial ekonomi masyarakat. Semakin banyak seseorang memiliki sesuatu yang berharga seperti rumah dan tanah, maka dapat dikatakan bahwa orang itu mempunyai kemampuan ekonomi yang tinggi dan mereka semakin dihormati oleh orang-orang di sekitarnya.

Menurut Kurnianto (2017) kepemilikan kekayaan yang bernilai ekonomis dalam berbagai bentuk dan ukuran seperti perhiasan, televisi, kulkas dan lain-lain dapat menunjukkan adanya pelapisan dalam masyarakat. Kemudian kendaraan pribadi dapat digunakan sebagai alat ukur tinggi rendahnya tingkat sosial ekonomi keluarga. Misalnya, orang yang mempunyai mobil akan merasa lebih tinggi tingkat taraf ekonominya dari pada orang yang mempunyai sepeda motor. Kepemilikan barang berharga yang dimaksud dalam penelitian ini yaitu kepemilikan alat transportasi seperti motor, sepeda, dan mobil.

\section{d) Interaksi sosial}

Menurut Nasdian (2015) interaksi sosial mempunyai tujuan tertentu, orang bertindak dan bereaksi terhadap yang lain dalam rangka mencapai tujuan mereka. Proses interaksi sosial merupakan basis untuk menciptakan struktur sosial. Kata sosial menyatakan bahwa lebih dari seorang yang terlibat, dan interaksi berarti bahwa terjadi saling memengaruhi satu sama lain. Interaksi berarti dua orang atau lebih terlibat dalam tindakan sosial bersama, setiap orang menjadi subjek sekaligus objek dari tindakan orang lain. Sebelum hubungan-hubungan sosial (interaksi sosial) tersebut menjadi suatu hubungan yang terpola (stabil), maka akan dialami suatu proses sosial menuju bentuk yang konkrit, suatu hubungan yang terpola sesuai dengan nilai-nilai sosial dan budaya dalam masyarakat. Kemudian, batasan interaksi sosial terbagi ke dalam tiga bagian, yaitu: (1) Hubungan antara perorangan. Apabila dua orang bertemu, dan kemudian saling bertegur sapa, berbicara, maka terjadi interaksi sosial; (2) Hubungan antara kelompok-kelompok manusia; dan (3) Hubungan antara peorangan dengan kelompok manusia.

\section{Sociopreneur}

Menurut Kamus Oxford (1998) dalam Prayogo (2017) entrepreneur adalah seseorang yang bertanggung jawab atas sebuah bisnis dengan mau menerima segala resikonya, untung atau rugi. Entrepreneur dapat digolongkan ke dalam dua kelompok, yaitu business entrepreneur dan social entrepreneur. Perbedaan pokok keduanya utamanya terletak pada pemanfaatan keuntungan. Business Entrepreneur merupakan wirausahawan yang mengambil keuntungan dari usahanya untuk ekspansi atau mengembangkan dan memperbesar usahanya, sedangkan Social entrepreneur (Sociopreneur) ialah wirausahawan yang mengambil keuntungan dari usahanya (sebagian atau seluruhnya) untuk diinvestasikan kembali guna membantu masyarakat.

Menurut Anas (2019) kemunculan dan perkembangan social enterpreneur sejalan dengan kemajuan teknologi informasi yang merubah cara pandang manusia terhadap perubahan lingkungan, terutama pada pertumbuhan ekonomi yang tidak sejalan dengan kesejahteraan masyarakat. Gap kemiskinan dan kesejahteraan menjadi isu yang belum pernah habis. Banyak orang berusaha melakukan berbagi aktivitas sosial untuk memperkecil kesenjangan. Tindakan sosial yang muncul atas dasar keprihatinan sosial untuk menyelesaikan persoalan kemiskinan dan kerusakan lingkungan yang disebabkan dampak bisnis. Sebagai bentuk keprihatinan sosial inilah upaya menggerakan sebagian orang untuk melakukan berbagai tindakan agar memberikan kemanfaatan sosial bagi masyarakat. Melihat fenomena sosial yang terjadi, memunculkan orangorang yang tergerak dalam hatinya secara khusus untuk menyelesaikan persosalan sosial masyarakat (kemiskinan, ksesehatan, pengangguran, dan lain-lain), tentunya orang-orang tersebut mempunyai ide, gagasan, dan visi agar persoalan masyarakat mendapatkan solusi untuk membentuk sebuah masyarakat yang sejahtera. Kemudian Anas (2029) menjelaskan lebih lanjut bahwa orang-orang yang tergerak mengimplementasikan visi-misi, ide dan gagasan sosial adalah pengusaha sosial atau social enterpreneur. Social enterpreneur merupakan individu yang 
mempunyai karakter kewirausahaan dan mampu mengidentifikasikan persoalan sosial yang digunakan sebagai pemecah persoalan sosial masyarakat.

Menurut penelitian yang dilakukan oleh Rusli et al. (2012) untuk mengatasi masalah kemiskinan salah satunya dengan pengembangan social entrepreneurship (sosial kewirausahaan) yaitu mengembangkan wirausahawan sosial dengan cara mengubah perilaku dan pemahaman atau kesadaran orang di sekitarnya. Wirausahawan sosial memiliki daya transformatif dengan gagasan-gagasan barunya dengan memanfaatkan dan menciptakan peluang dalam menghadapi masalah besar, yang tidak kenal lelah mewujudkan visinya sampai berhasil menyebarkan gagasan yang dimilikinya. Selain itu, menurut Muryanti (2020) kewirausahaan sosial memiliki tujuan yang eksplisit berdasarkan pada sebuah gerakan yang didorong oleh semangat untuk menolong orang lain dan membuat perubahan untuk kebaikan masyarakat. Wirausaha sosial adalah mereka yang memiliki pengetahuan modal (Sumber Daya Manusia), modal sosial, dan keterampilan sosial yang mengubah masalah sosial menjadi inovasi sosial. Cara terbaik untuk mengukur kewirausahaan sosial bukan dengan menghitung jumlah keuntungan yang idhasilkan tetapi pada tingkat dimana kegiatan ekonomi juga menghasilkan nilai-nilai sosial. Menurut Prayogo (2017) prinsip yang dimiliki oleh seorang sociopreneur adalah banyak memberi daripada menerima. Sehingga para sociopreneur akan selalu mengembangkan usahanya agar dapat semakin banyak menopang orang-orang yang kesusahan. Sociopreneur bertindak sebagai agen perubahan bagi masyarakat. Mulai dari memiliki pandangan baru, perbaikan sistem ekonomi, menemukan pendekatan baru, hingga dapat menemukan solusi untuk mengubah kehidupan masyarakat menjadi lebih baik, terutama untuk masyarakat menengah ke bawah.

Sociopreneur dan social enterpreneur mempunyai perbedaan istilah namun mempunyai arti yang sama, yaitu seseorang yang melakukan usaha atau bisnis yang beorientasi pada tujuan-tujuan sosial. Kependekan istilah dari social enterpreneur menjadi socipreneur, teknologi enterpreneur menjadi tecnopreneur, digital enterpreneur menjadi digipreneur, hal tersebut sudah lazim sering digunakan di Indonesia (Anas 2019).

Kegiatan kewirausahaan sosial pada tingkat individu dapat mengurangi tingkat pengangguran dengan menciptakan lapangan kerja, dan pada tingkat kelompok dapat mengurangi tingkat kemiskinan di masyarakat dan menyelesaikan berbagai masalah sosial seperti pendidikan dan kesehatan (Firdaus 2014). Hadirnya seorang entrepreneur memang dapat menciptakan dan membuka industri baru, tetapi hadirnya seorang sociopreneur akan membawa perubahan bagi masyarakat serta menemukan solusi baru untuk mengatasi masalah-masalah yang terjadi. Seorang sociopreneur akan memperlebar usahanya demi membantu masyarakat. Salah satu tindakan sociopreneur dalam mengatasi permasalahan tersebut salah satunya dengan mengembangkan UMKM. Berdasarkan Undang-Undang Republik Indonesia Nomor 20 Tahun 2008 tentang Usaha Mikro, Kecil, dan Menengah pada Pasal 5 dijelaskan mengenai tujuan pemberdayaan Usaha Mikro, Kecil, dan Menengah yaitu meliputi (a) Mewujudkan struktur perekonomian nasional yang seimbang, berkembang, dan berkeadilan; (b) Menumbuhkan dan mengembangkan kemampuan Usaha Mikro, Kecil, dan Menengah menjadi usaha yang tangguh dan mandiri; dan (c) meningkatkan peran Usaha Mikro, Kecil, dan Menengah dalam pembangunan daerah, penciptaan lapangan kerja, pemerataan.

\section{Karakteristik Sociopreneur}

Karakteristik Sociopreneur atau kewirausahaan sosial meliputi menciptakan nilai sosial, wirausaha sosial, organisasi kewirausahaan sosial, orientasi pasar, dan inovasi sosial (Masturin 2015): (1) Menciptakan nilai sosial, prasyarat terbentuknya kewirausahaan sosial adalah terciptanya nilai sosial yang didalamnya mencakup misi sosial dan berperan dalam memenuhi kebutuhan sosial berupa kekayaan sosial. Konsep penciptaan nilai sosial ini sarat konsep nilai yang melibatkan perilaku saleh, tujuan altruistik, dan dukungan terhadap tujuan sosial seperti 
kemerdekaan, kesetaraan, dan toleransi; (2) Wirausaha sosial, aspek lain yang terintegralistik dari kewirausahaan sosial adalah wirausaha sosial secara individu. Peran wirausaha sosial penting dalam kegiatan sosial dan proses perubahan sosial baik sebagai inisiator maupun inovator sosial. Individu dalam kewirausahaan sosial harus visioner, berani mengambil risiko, dan inovatif. Usaha sosial ini mengejar peluang untuk melakukan katalisasi perubahan sosial dan memenuhi kebutuhan sosial dan diciptakan untuk mengatasi masalah-masalah sosial; (3) Organisasi kewirausahaan sosial, organisasi kewirausahaan sosial dapat berupa organisasi laba, nirlaba, hibrid, atau komunitas-komunitas sosial baik itu milik masyarakat atau swasta dalam sektor apapun yang ditujukan untuk mencapai perubahan sosial; dan (4) Orientasi pasar, aspek orientasi pasar dalam kewirausahaan sosial berkaitan dengan gagasan efisiensi tinggi dan efektifitas melalui kegiatan komersil dan keberlanjutan keuangan dan swasembada. Orientasi pasar bertujuan untuk memberikan nilai positif atau menerapkan karakter kewirausahaan sosial seperti perilaku disiplin, inovatif, dan memiliki tekad kuat.

\section{Persepsi Sosial}

Myers (2012) mengatakan bahwa persepsi merupakan sebuah arahan seseorang untuk berperilaku. Persepsi dapat menjadi panduan atas tindakan berdasarkan makna yang diberikan pada stimulus yang dirasakan. Pengertian ini didasarkan pada saat terdapat suatu stimulus yang menarik perhatiannya, maka yang akan terjadi adalah suatu proses perceiving dan meaning. selain itu, terdapat pula interpretasi terhadap simbol-simbol yang ada pada stimulus tersebut. Proses persepsi tersebut dipengaruhi oleh konteks dimana individu tersebut berada.

Menurut Thoha (2001) persepsi pada hakikatnya adalah proses kognitif yang dialami oleh setiap orang di dalam memahami informasi tentang lingkungannya, baik lewat penglihatan, pendengaran, penghayatan, perasaan, dan penciuman. Kunci untuk memahami persepsi adalah terletak pada pengenalan bahwa persepsi itu merupakan suatu penafsiran yang unik terhadap situasi dan bukan suatu pencatatan yang benar terhdap situasi.

Kemudian menurut Baron dan Byrne (2004) persepsi sosial merupakan proses yang kita gunakan untuk mencoba mengetahui dan memahami orang lain.

Taylor et al. (2009) berpendapat bahwa persepsi sosial adalah bagaimana manusia membentuk kesan terhadap orang lain, jenis informasi apa yang kita gunakan untuk mendapatkan kesan itu, seberapa akuratkah kesan kita, dan bias apa yang memengaruhi kesan. Manusia menggunakan apapun informasi yang tersedia untuk membentuk kesan kita tentang orang lain yaitu dengan membuat penilaian tentang kepribadiannya atau menyusun hipotesis tentang jenis orang itu. Menurut Taylor et al. (2009) dalam mengkaji bagaimana orang membentuk kesan tentang orang lain, terdapat enam prinsip umum dan sederhana: (1) Orang membentuk kesan tentang orang lain dengan cepat berdasarkan informasi minimal dan kemudian menyebut ciri-ciri umum daari orang lain; (2) Orang memberi perhatian khusus pada ciri yang paling menonjol dari seseorang, bukan memerhatikan seluruh ciri seseorang; (3) Dalam memproses informasi tentang orang lain kita akan memberi makna yang koheren pada perilaku mereka; (4) Kita menata persepsi kita dengan mengorganisasikan atau mengelompokkan stimuli; (5) Kita menggunakan struktur kognitif kita untuk memahami perilaku orang lain; dan (5) Kebutuhan pihak yang memahami dan tujuan personal juga akan memengaruhi bagaimana dia memandang orang lain.

Selanjutnya menurut Rahman (2013) persepsi sosial adalah suatu usaha untuk memahami orang lain dan diri kita sendiri. Sebagai objek, banyak aspek dari manusia yang bisa dipersepsi. Aspekaspek tersebut bisa berupa: (1) Aspek fisik: daya tahan fisik, daya tarik fisik, kecepatan, kekuatan, tinggi badan, berat badan, kesehatan, kebugaran, kelenturan, warna kulit, kualitas suara, warna rambut, bentuk muka, bentuk hidung, dan lain-lain; (2) Aspek psikologis: kepribadian, sikap, motivasi, stabilitas emosi, kecerdasan, minat, kesabaran, dan lain-lain; (3) Aspek sosio-kultural: 
keterampilan sosial, keberanian, konformitas, integrasi sosial, intensi prososial, kepekaan sosial, kemandirian, dan lain-lain; dan (4) Aspek spiritual: orientasi beragama, integritas moral, perilaku beribadah, dan lain-lain.

Rahman (2013) pula menjelaskan bahwa persepsi sosial bersifat selektif. Tidak semua aspek dari orang lain menjadi objek persepsi kita, adakalanya kita lebih tertarik untuk memahami aspek fisiknya, psikologis, sosial, dan/atau spiritualnya. Di dalam memahami orang lain, manusia kadang hanya mengandalkan shortcut mental. Pada saat itu pemahaman sosial menjadi lebih cepat, tetapi keakuratan dikorbankan.

\section{Hubungan Kondisi Sosial Ekonomi Pemilik UMKM dengan Persepsi terhadap Karakteristik Sociopreneur}

Menurut Sholikhatun (2010) persepsi merupakan cara pandang seseorang terhadap suatu objek dengan mempertibangkan segala aspek yang berkaitan dengan dirinya dan lingkungannya. Ada beberapa faktor yang mempengaruhi persepsi seseorang terhadap suatu cara atau usaha yang dilakukan oleh sociopreneur dalam mengembangkan UMKM, yang akhirnya dapat menerima bahkan menerapkan cara-cara tersebut. Faktor tersebut antara lain meliputi pendidikan formal, tingkat pendapatan, kepemilikan, serta pola interaksi sosial. Persepsi pemilik UMKM inilah yang nantinya dapat menjadi masukan bagi keberhasilan sociopreneur dalam usaha mengembangkan UMKM.

Sukmadi (2016) mengatakan bahwa sukses atau tidaknya seorang sociopreneur dapat dilihat dari dampak yang diciptakan di masyarakat. Adanya kemampuan memahami suatu permasalahan sosial serta menggunakan prinsip-prinsip kewirausahaan untuk mengorganisasi, menciptakan, serta mengelola suatu usaha untuk menggerakkan perubahan sosial. Sociopreneur menjalankan bisnis sosial yang merupakan usaha-usaha menciptakan produk barang dan jasa untuk memaksimalkan manfaat sosial. Penjualan ini bukan untuk mengejar keuntungan tetapi dapat memberikan manfaat secara maksimal pada anggota masyarakat lainnya.

Berdasarkan penelitian Salim (2018) pemberdayaan masyarakat dan kegiatan ekonomi berpengaruh positif signifikan terhadap keberhasilan usaha. Hal ini dapat dilihat dari keberhasilan sociopreneur dalam mengembangkan UMKM di pedesaan. Ketika persepsi pemilik UMKM positif terhadap karakteristik sociopreneur dalam menjalankan cara atau usaha dalam mengembangkan UMKM, maka respon mereka pun akan positif terhadap usaha-usaha yang dilakukan oleh sociopreneur. Maka dari itu, akan berdampak positif pada kemajuan dan perkembangan usaha yang dilakukan pemilik UMKM sehingga akan tumbuh menjadi UMKM yang berdaya saing.

\section{METODE PENELITIAN}

\section{Metode dan Pendekatan Penelitian}

Pendekatan yang digunakan dalam penelitian mengenai hubungan kondisi sosial ekonomi pemilik UMKM dengan persepsi terhadap karakteristik sociopreneur ini merupakan penelitian yang menggunakan pendekatan kuantitatif yang didukung oleh data kualitatif. Pendekatan kuantitatif dilakukan dengan metode sensus, yaitu metode pengambilan sampel dimana semua anggota populasi diambil sebagai anggota sampel yang pengumpulan datanya melalui instrumen dengan menggunakan kuesioner. Pendekatan kuantitatif yang digunakan bertujuan untuk mengetahui hubungan kondisi sosial ekonomi pemilik UMKM dengan persepsi terhadap karakteristik sociopreneur. Sementara itu, data kualitatif digunakan untuk menggali informasi yang sifatnya lebih dalam serta untuk memperjelas gambaran tentang keadaan sosial yang diperoleh melalui pendekatan kuantitatif (Singarimbun dan Effendi 2014). Data kualitatif diperoleh melalui observasi lapang, studi literatur serta wawancara mendalam yang dilakukan kepada informan atau 
responden dengan menggunakan panduan pertanyaan yang dilakukan oleh peneliti di lokasi penelitian. Hal ini bertujuan untuk mengetahui peranan sociopreneur dalam penegembangan Kampung Wisata Bisnis Tegalwaru (KWBT). Data hasil wawancara digunakan sebagai pelengkap atau pendukung untuk menyempurnakan pertanyaan pada kuesioner.

Sebelum dilakukan penelitian, dilakukan uji validitas dan realibilitas terhadap instrumen penelitian kepada 10 responden di lokasi penelitian. Uji validitas dilakukan untuk menunjukkan sejauh mana alat pengukur yang digunakan sesuai dengan mengukur apa yang ingin diukur, sedangkan uji reliabilitas digunakan untuk menunjukkan sejauh mana suatu alat ukur dapat dipercaya atau dapat diandalkan apabila digunakan dua kali untuk mengukur gejala yang sama dan hasil pengukuran yang diperoleh relatif konsisten.

\section{Lokasi dan Waktu Penelitian}

Lokasi yang dipilih untuk penelitian adalah di Desa Tegalwaru, Kecamatan Ciampea, Kabupaten Bogor, Jawa Barat. Pemilihan lokasi penelitian ini dilakukan secara purposive (sengaja) dikarenakan alasan sebagai berikut: Desa Tegalwaru merupakan salah satu desa di Kecamatan Ciampea yang memiliki seorang sociopreneur yang berprestasi: (1) Adanya Kampung Wisata Bisnis Tegalwaru yang didirikan sekitar 9 tahun yang lalu dengan bermacam-macam UMKM di dalamnya; dn (2) Desa Tegalwaru merupakan desa yang menjadi percontohan bagi desa lain.

Penelitian ini dilaksanakan dalam waktu sekitar enam bulan terhitung mulai bulan Agustus 2019 hingga Januari 2020. Kegiatan penelitian ini meliputi penyusunan proposal skripsi, kolokium, perbaikan proposal skripsi, pengambilan data lapang, pengolahan dan analisis data, dan penyusunan draft skripsi.

\section{Jenis Data dan Teknik Pengumpulan Data}

Data yang digunakan dalam penelitian ini terdiri dari dua jenis data yaitu data primer dan data sekunder yang dapat bersifat kuantitatif dan kualitatif. Data primer yang bersifat kuantitatif diperoleh dengan melalui sensus kepada responden di lapangan menggunakan kuesioner sebagai alat pengumpulan data yang utama. Data primer juga didapatkan melalui observasi lapang dan wawancara dengan menggunakan panduan wawancara yang ditanyakan kepada informan. Selain itu, data kualitatif penelitian ini mencoba menggali aktor sehingga dibutuhkan pendekatan biografi aktor yang meliputi sejarah perjalanan aktor dalam pengembangan Kampung Wisata Bisnis Tegalwaru. Sedangkan untuk data sekunder diperoleh melalui informasi tertulis, data-data dan literatur yang mendukung kebutuhan data mengenai fokus penelitian dan berbagai literatur terkait penelitian yang akan dilakukan.

\section{Penentuan Responden dan Informan Penelitian}

Sumber data pada penelitian ini yaitu responden dan informan. Responden adalah seseorang yang dapat memberikan informasi mengenai dirinya sendiri sebagai sumber utama yang diperlukan. Populasi dalam penelitian ini yaitu seluruh pemilik Usaha Mikro Kecil dan Menengah (UMKM) yang berada di Desa Tegalwaru. Unit analisis dalam penelitian ini adalah individu. Teknik pengambilan sampel penelitian dilakukan dengan cara sampel jenuh atau sensus. Hal tersebut dilakukan karena jumlah populasi penelitian hanya terdiri dari 33 pemilik UMKM aktif di Desa Tegalwaru sehingga seluruh anggota populasi digunakan sebagai anggota sampel dan juga sebagai responden.

Selanjutnya, informan adalah seseorang yang memberikan informasi tambahan yang berkaitan dengan keterangan dan gambaran terkait diri dan lingkungan tempat tinggalnya sehingga keberadaannya sangat penting untuk memberikan keterangan yang dimiliki. Informan dalam penelitian ini adalah Kepala Desa Tegalwaru, aparat desa, aktor yang mejadi sociopreneur, dan sebagian tokoh masyarakat setempat. Informan-informan tersebut dipilih secara purposive karena dianggap mengetahui dengan jelas mengenai pengembangan Kampung Wisata Bisnis Tegalwaru dan hubungannya dengan kondisi kehidupan sosial ekonomi masyarakat desa sebagai pemilik UMKM di Desa Tegalwaru. 


\section{Teknik Pengolahan dan Analisis Data}

Data yang diperoleh pada penelitian ini berupa data kuantitatif dan data kualitatif. Data kuantitatif berasal dari hasil pengisian kuesioner oleh responden terkait dengan variabel yang diteliti kemudian dianalisis dengan Microsoft Excel 2010 dan diolah menggunakan aplikasi Statistical Program for Social Sciences (SPSS) for windows versi 21 dengan menggunakan korelasi Rank Spearman untuk melihat tingkat kekuatan (keeratan) hubungan dua variabel, melihat arah (jenis) hubungan dua variabel, dan signifikansi hubungan antar variabel. Sebelum data diolah dan dianalisis, tahap pertama yang dilakukan adalah mengecek kelengkapan jawaban yang diperoleh dari kuesioner. Microsoft Excel 2010 digunakan untuk pembuatan tabel frekuensi, grafik, serta tabel tabulasi silang untuk melihat data awal responden untuk masing-masing variabel.

Pengelompokkan masing-masing peubah dijadikan kedalam tiga kategori yaitu rendah, sedang, dan tinggi. Variabel-variabel yang diuji adalah variabel kondisi sosial ekonomi masyarakat desa yang memiliki UMKM dengan persepsi terhadap karakteristik sociopreneur. Pembuktian hipotesis mengenai hubungan antara variabel kondisi sosial ekonomi pemilik UMKM dengan variabel persepsi terhadap karakteristik sociopreneur dilakukan melalui uji korelasi Rank Spearman. Uji korelasi dilakukan dengan kriteria kekuatan hubungan menurut Sugiyono (2013) yang disajikan pada Tabel 1 .

Tabel 1 Kriteria diterima dan ditolak hipotesis penelitian berdasarkan uji korelasi Rank Spearman

\begin{tabular}{|c|c|c|}
\hline Parameter & Nilai & Interpretasi \\
\hline \multirow[t]{5}{*}{$\begin{array}{l}\text { Kekuatan korelasi } \\
\rho \text { hitung }\end{array}$} & $\begin{array}{c}0,000- \\
0,199\end{array}$ & Korelasi sangat lemah \\
\hline & $\begin{array}{c}0,200- \\
0,399\end{array}$ & Korelasi lemah \\
\hline & $\begin{array}{c}0,400- \\
0,599\end{array}$ & Korelasi sedang \\
\hline & $\begin{array}{c}0,600- \\
0,799\end{array}$ & Korelasi kuat \\
\hline & $\begin{array}{c}0,800- \\
1,000\end{array}$ & Korelasi sangat kuat \\
\hline \multirow[t]{2}{*}{$\begin{array}{l}\text { Arah korelasi } \\
\text { hitung }\end{array}$} & $\begin{array}{c}+ \\
+ \\
\text { (positif) }\end{array}$ & $\begin{array}{l}\text { Searah, semakin besar xi } \\
\text { semakin besar pula yi }\end{array}$ \\
\hline & $\begin{array}{c}- \\
\text { (negatif) }\end{array}$ & $\begin{array}{l}\text { Berlawanan arah, } \\
\text { semakin besar xi semakin } \\
\text { kecil yi, dan sebaliknya }\end{array}$ \\
\hline
\end{tabular}

Sumber: Sugiyono (2013)

Selain analisis data kuantitatif, dilakukan pula analisis data kualitatif. Data kualitatif sendiri dapat digunakan untuk mendukung data kuantitatif dalam bentuk deskriptif. Data deskriptif tersebut diperoleh melalui hasil wawancara mendalam kepada responden ataupun informan sehingga dapat mendukung data kuantitaif yang diperoleh melalui kuesioner. Pengolahan data kualitatif tersebut dianalisis melalui reduksi data, penyajian data, dan penarikan kesimpulan untuk memperkuat hasil penelitian. Reduksi data adalah merangkum, memilih hal-hal yang pokok dan memfokuskan pada hal-hal yang menjadi objek penelitian. Kemudian, penyajian data adalah proses penyusunan informasi secara sistematik dalam rangka memperoleh kesimpulankesimpulan sebagai temuan penelitian. Penyajian data dimaksudkan agar memudahkan bagi peneliti untuk melihat gambaran secara keseluruhan atau bagian-bagian tertentu dari penelitian. Dengan demikian, data yang telah direduksi akan memberikan gambaran yang lebih jelas dan mempermudah peneliti untuk melakukan pengumpulan data dan penarikan kesimpulan untuk memperkuat hasil penelitian. 


\section{HASIL DAN PEMBAHASAN}

\section{Kondisi Sosial Ekonomi Pemilik UMKM}

Sub bab ini menguraikan analisis tentang kondisi sosial ekonomi pemilik UMKM. Tujuan dari analisis ini adalah untuk mengetahui kondisi sosial ekonomi pemilik UMKM setelah adanya sociopreneur di Desa Tegalwaru. Indikator yang digunakan adalah dengan mengukur tingkat pendidikan, tingkat pendapatan, alat kepemilikan transportasi, dan pola interaksi.

Tabel 2 Jumlah dan persentase kondisi sosial ekonomi pemilik Usaha Mikro Kecil dan Menengah (UMKM) secara keseluruhan

\begin{tabular}{lrr}
\hline Kondisi Sosial Ekonomi & Jumlah & Persentase \\
\hline Rendah & 7 & 21.2 \\
Tinggi & 26 & 78.8 \\
\hline Jumlah & 33 & 100.0 \\
\hline
\end{tabular}

Berdasarkan Tabel 6, kondisi sosial ekonomi pemilik Usaha Mikro Kecil dan Menengah (UMKM) di Desa Tegalwaru berada pada kategori tinggi dengan jumlah responden sebanyak 26 orang dengan persentase sebesar 78,8 persen. Adapun responden yang memiliki kondisi sosial ekonomi yang termasuk ke dalam kategori rendah yaitu sebanyak 7 orang dengan persentase sebesar 21,2 persen. Hal tersebut dikarenakan masih terdapat responden yang belum dapat mengoptimalkan usahanya, seperti dalam hal pemasaran dan juga kalah saing dengan produk luar negeri.

\section{Tingkat Pendidikan}

Tingkat pendidikan merupakan salah satu indikator dalam menganalisis kondisi sosial ekonomi. Pendidikan memegang peranan penting dalam membentuk dan menciptakan masyarakat sesuai yang diharapkan, karena pendidikan berfungsi untuk mengembangkan wawasan dan meningkatkan kualitas manusia terhadap agama, ekonomi, dan sosial sehingga dapat membawa masyarakat untuk mencapai tujuan pembangunan nasional (Erista, 2014). Maka dari itu, penelitian ini melihat tingkat pendidikan pemilik Usaha Mikro, Kecil, dan Menengah (UMKM) di Desa Tegalwaru dalam tingkat pendidikannya. Tabel 19 menunjukkan jumlah dan persentase para pemilik UMKM berdasarkan tingkat pendidikan.

Tabel 3 Jumlah dan persentase responden berdasarkan tingkat pendidikan

\begin{tabular}{crr}
\hline Tingkat Pendidikan & Jumlah & Persentase \\
\hline Rendah & 26 & 78.8 \\
Tinggi & 7 & 21.2 \\
\hline Jumlah & 33 & 100.0 \\
\hline
\end{tabular}

Pemilik UMKM di Desa Tegalwaru mayoritas memiliki tingkat pendidikan yang rendah. Berdasarkan Tabel 7 diperoleh informasi bahwa persentase pada kategori rendah yaitu sebesar 78,8 persen atau sebanyak 26 responden. Tingkat pendidikan dalam penelitian ini dikelompokan ke dalam dua kategori yaitu rendah dan tinggi. Tingkat pendidikan termasuk ke dalam kategori rendah apabila pendidikan terakhir pemilik UMKM tidak sekolah, tamat SD, dan tamat SMP, sedangkan tingkat pendidikan termasuk ke dalam kategori tinggi apabila pendidikan terakhir responden tamat SMA, D3/D4, dan sarjana. Meski mayoritas tingkat pendidikan responden sebagai pemilik UMKM berada pada kategori rendah, tetapi tidak mempengaruhi mereka dalam menjalankan dan mengembangkan usahanya. Hal ini dikarenakan pemilik UMKM dapat belajar 
secara nonformal darimana saja seperti pelatihan-pelatihan yang diselenggarakan oleh beberapa instansi pemerintah, belajar dari kegiatan keterampilan yang diselenggarakan oleh sociopreneur, maupun belajar dari pengalaman dan dari UMKM yang lain.

"Saya mah lulus SD doang, cuma dulu kan kerja sama Cina ya bikin roti juga. Setelah ilmunya cukup saya coba buka usaha sendiri sambil sekolah usaha gitu di daerah Cibinong” (JPR, 41 Tahun)

"Ilmu bisa diperoleh darimana saja kan, walaupun saya udah tua tapi saya suka ikut pelatihan-pelatihan, kadang sampai dua atau tiga hari di luar kota, walaupun pakai biaya sendiri tapi saya senang bisa dapat pengetahuan baru, pengalaman, sekalian jalan-jalan kan." (STH, 72 Tahun)

\section{Tingkat Pendapatan}

Sub bab ini menguraikan tingkat pendapatan dari pelaku Usaha Mikro, Kecil, dan Menengah (UMKM) di Desa Tegawaru. Menurut Sukirno (2011) pendapatan adalah jumlah penghasilan yang diterima oleh penduduk atas prestasi kerjanya selama satu periode tertentu, baik harian, mingguan, bulanan ataupun tahunan. Sedangkan menurut Sukmawari (2013) pendapatan adalah jumlah keseluruhan dari hasil yang diperoleh baik dari pekerjaan pokok maupun pekerjaan sampingan yang dapat dilihat dan diukur dengan rupiah dalam waktu tertentu. Penelitian ini melihat seberapa besar pendapatan yang diperoleh oleh pelaku UMKM setelah adanya Kampung Wisara Bisnis Tegalwaru.

Tabel 4 Jumlah dan persentase responden berdasarkan tingkat pendapatan

\begin{tabular}{lrc}
\hline Tingkat Pendapatan & Jumlah & \multicolumn{2}{c}{ Persentas } \\
& & e \\
\hline Rendah & 8 & 24.2 \\
Tinggi & 25 & 75.8 \\
\hline Jumlah & 3 & 100.0 \\
\hline
\end{tabular}

Pengukuran tingkat pendapatan dilakukan dengan mengukur jumlah pendapatan yang didapatkan selama sebulan dalam satuan rupiah. Berdasarkan Surat Edaran Gubernur Jawa Barat Nomor 561/75/Yanbangsos Tanggal 21 November 2019 Tentang Pelaksanaan Upah Minimum Kabupaten/Kota di Daerah Provinsi Jawa Barat Tahun 2020, Kabupaten Bogor tercantum sebesar Rp.4.083.670,00. Tingkat pendapatan dalam penelitian ini dibagi kedalam dua kategori, yaitu rendah dan tinggi. Tingkat pendapatan termasuk ke dalam kategori rendah apabila pendapatan perbulannya kurang dari 4.083.670 rupiah, dan yang termasuk ke dalam kategori tinggi apabila pendapatan perbulannya lebih dari 4.083 .670 rupiah.

Berdasarkan Tabel 8 dapat diketahui bahwa sebesar 24,2 persen atau sebanyak 8 responden berada pada tingkat pendapatan kategori rendah dan kategori tinggi sebanyak 25 responden dengan persentase sebesar 75,8 persen. Berdasarkan tabel diperoleh mayoritas responden memiliki tingkat pendapatan yang tinggi, yaitu diatas Upah Minimum Kabupaten Bogor. Menurut Kepala Desa Tegalwaru sebenarnya pendapatan para pelaku UMKM ini bisa lebih meningkat, tetapi ada beberapa produk yang kalah saing dengan produk China atau luar negeri yang harga jualnya lebih murah.

"Kalau sebelumnya itu engga bisa dipastiin yaa, engga tentu, karena kadang-kadang saya nyari pasaran tuh susah banget. Kalo perbulannya dulu sebelum ada KWBT yaitu 
sekitar 2 jutaan, kalau sekarang dihitung rata-rata 5 jutaan ada juga lebih. Menurut duniawi orang engga ada puasnya, kita bersyukur aja, cukup ajalah berapapun kita dikasih rejeki." (RJY, 54 Tahun)

\section{Kepemilikan Alat Transportasi}

Pemilikan kekayaan atau fasilitas adalah kekayaan dalam bentuk barang yang masih bermanfaat dalam menunjang ekonomi. Menurut Kurnianto (2017) kepemilikan kekayaan yang bernilai ekonomis dalam berbagai bentuk dan ukuran seperti perhiasan, televisi, kulkas dan lain-lain dapat menunjukkan adanya pelapisan dalam masyarakat. Kemudian kendaraan pribadi dapat digunakan sebagai alat ukur tinggi rendahnya tingkat sosial ekonomi keluarga. Misalnya, orang yang mempunyai mobil akan merasa lebih tinggi tingkat taraf ekonominya dari pada orang yang mempunyai sepeda motor. Kepemilikan barang berharga yang dimaksud dalam penelitian ini yaitu kepemilikan alat transportasi seperti motor, sepeda, dan mobil yang dimiliki oleh pelaku UMKM. Tabel 15 menunjukkan jumlah dan presentase kepemilikian alat transportasi yang dimiliki oleh pelaku UMKM.

Tabel 5 Jumlah dan persentase responden berdasrkan kepemilikan alat transportasi

\begin{tabular}{crr}
\hline Kepemilikan Alat Transportasi & Jumlah & Persentase \\
\hline Rendah & 13 & 39,4 \\
Tinggi & 20 & 60,6 \\
\hline Jumlah & \multirow{2}{*}{33} & 100, \\
& & 0 \\
\hline
\end{tabular}

Tabel 9 menunjukan kepemilikan alat transportasi para pemilik Usaha Mikro Kecil dan Menengah (UMKM) di Desa Tegalwaru mayoritas terdapat pada kategori tinggi yaitu sebanyak 20 responden dengan 60,6 persen, dan sisanya sebanyak 13 responden dengan 39,4 persen berada pada kategori rendah. Para pemilik UMKM telah memiliki kendaraan pribadi dalam menunjang keberlangsungan usahanya yang juga dimanfaatkan dalam kehidupan sehari-harinya.

\section{Pola Interaksi}

Pola interaksi merupakan suatu bentuk jalinan interaksi yang terjadi di antara individu dan individu, individu dan kelompok, atau kelompok dan kelompok yang bersifat dinamis dan memiliki pola tertentu. Pola interaksi yang diamati dalam penelitian ini yaitu bagaimana pola interaksi yang terjadi pada individu dan individu, yakni pemilik Usaha Mikro Kecil dan Menengah (UMKM) yang ada di Desa Tegalwaru dengan sociopreneur. Hal ini akan memperlihatkan apakah seorang pemilik UMKM masih bisa menyempatkan waktunya dalam berinteraksi dengan sociopreneur atau memang hanya fokus dalam menjalankan aktivitasnya sebagai pelaku usaha. Pola interaksi ini dilihat dari frekuensi pemilik UMKM mengikuti kegiatan yang diselenggarakan oleh sociopreneur. Interaksi tersebut dinilai dari seberapa sering mengikuti kegiatan tersebut, apakah tidak pernah, jarang, sering, atau selalu. Maka Tabel 16 menyajikan jumlah dan persentase responden dalam pola interaksinya.

Tabel 6 Jumlah dan persentase responden berdasarkan pola interaksi

\begin{tabular}{lrr}
\hline Pola Interaksi & Jumlah & Persentase \\
\hline Rendah & 26 & 78.8 \\
Tinggi & 7 & 21.2 \\
\hline Jumlah & 33 & 100.0 \\
\hline
\end{tabular}

Tabel 10 menunjukkan pola interaksi pemilik Usaha Mikro Kecil dan Menengah (UMKM) dengan sociopreneur mayoritas terdapat pada kategori rendah yaitu sebanyak 26 responden atau sebesar 78,8 persen dan kategori tinggi sebanyak 7 responden dengan 21,2 persen. Hasil tersebut 
menunjukkan bahwa beberapa pemilik UMKM memiliki kesibukan masing-masing, dan jarak yang cukup jauh antara tempat tinggal mereka dengan tempat kegiatan yang diselenggarakan oleh sociopreneur. Bahkan, terdapat juga responden yang tidak pernah mengikuti kegiatan yang diselenggarakan oleh sociopreneur tersebut.

"Ai ngiring mh sok aya ngiring, tapi saya mh jarang da kadang posisi sok tara aya di imah, atau sibuk ngepak" (kalau ikutan suka ada ikutan, tapi saya kan kadang jarang ada di rumah, atau kalau di rumah pun sibuk ngepak (buat jualan). (MDI, 36 Tahun)

\section{Karakteristik Sociopreneur}

Karakteristik yaitu mempunyai sifat khas sesuai dengan perwatakan tertentu. Karakteristik dalam kasus ini adalah karakteristik seorang sociopreneur di Desa Tegalwaru, Kecamatan Ciampea, Kabupaten Bogor dalam pengembangan Usaha Mikro Kecil dan Menengah (UMKM). Penelitian ini mengukur persepsi responden sebagai pemilik UMKM terhadap karakteristik sociopreneur yang terdiri dari menciptakan nilai sosial, wirausaha sosial, organisasi kewirausahaan sosial, dan orientasi pasar dalam upaya peningkatan kondisi sosial ekonomi pemilik UMKM. Karakteristik sociopreneur dalam upaya peningkatan kondisi sosial ekonomi pemilik UMKM disajikan dalam Tabel 11.

Tabel 7 Jumlah dan persentase persepsi responden sebagai pemilik Usaha Mikro Kecil dan Menengah (UMKM) terhadap karakteristik sociopreneur

\begin{tabular}{crr}
\hline & Jumlah & Persentase \\
\hline Rendah & 0 & 0 \\
Sedang & 5 & 15.2 \\
Tinggi & 28 & 84.2 \\
\hline Jumlah & 33 & 100.0 \\
\hline
\end{tabular}

Secara keseluruhan, jika dilihat dari persepsi responden terhadap beberapa karakteristik seorang sociopreneur yang terdiri dari menciptakan nilai sosial, wirausaha sosial, organisasi kewirausahaan sosial, dan orientasi pasar terlihat bahwa karakteristik sociopreneur tersebut secara keseluruhan termasuk ke dalam kategori tinggi dengan persentase sebesar 84,2 persen. Persepsi responden terhadap karakteristik seorang sociopreneur yang tergolong tinggi dapat dijelaskan oleh beberapa indikator karakteristik sociopreneur sebagai berikut:

\section{Menciptakan Nilai Sosial}

Karakteristik sociopreneur dalam aspek menciptakan nilai sosial dalan penelitian ini yaitu bagaimana seorang sociopreneur dapat melihat potensi dan mengembangkan sumberdaya yang ada, baik itu sumberdaya alam dan juga sumberdaya manusianya. Karakteristik sociopreneur dalam aspek menciptakan nilai sosial yang diamati dalam penelitian ini terdiri dari tiga komponen atau indikator, yaitu (1) mengajak orang lain untuk bekerja sama, (2) memberikan santunan ketika menjelang Hari Raya Idul Fitri, (3) mengadakan agenda pertemuan secara rutin satu bulan satu kali. Adapun persepsi responden terhadap karakteristik sociopreneur dalam aspek menciptakan nilai sosial disajikan pada Tabel 12. 
Tabel 8 Jumlah dan persentase persepsi responden terhadap karakteristik sociopreneur dalam aspek menciptakan nilai sosial

\begin{tabular}{ccr}
\hline Persepsi terhadap aspek menciptakan nilai sosial & Jumlah & Persentase \\
\hline Rendah & 0 & 0 \\
Sedang & 19 & 57.6 \\
Tinggi & 14 & 42.4 \\
\hline Jumlah & 33 & 100.0 \\
\hline
\end{tabular}

Tabel 12 menunjukkan persepsi responden terhadap karakteristik sociopreneur di Desa Tegalwaru dalam aspek menciptakan nilai sosial. Persentase yang tergolong tinggi yaitu sebesar 42,4 persen, sedangkan persentase yang tergolong sedang yaitu sebesar 57,6 persen.

Persepsi masyarakat terhadap karakteristik sociopreneur dalam aspek menciptakan nilai sosial tergolong sedang dan tinggi, hal tersebut dibuktikan bahwa beberapa masyarakat sangat merasakan manfaat dari adanya sociopreneur tersebut. Karakteristik dalam menciptakan nilai sosial yang dilakukan sociopreneur dalam hal ini ditunjukkan dalam beberapa bentuk. Salah satunya yaitu kemampuan sociopreneur dalam melibatkan berbagai pihak, khususnya para wirausaha UMKM yang ada di Desa Tegalwaru. Langkah pertama yang dilakukan sociopreneur yaitu dengan cara sosialisai kepada masyarakat setempat, menyampaikan maksud dan tujuan dengan dibuatnya Kampung Wisata Bisnis Tegalwaru. Hal tersebut menuai pro-kontra masyarakat, tetapi karena memang tujuannya baik untuk mengembangkan desa khususnya para UMKM disana, sociopreneur memberikan pengertian secara perlahan bagi masyarakat yang tidak setuju dengan adanya Kampung Wisata Bisnis Tegalwaru tersebut.

"Kalo bermitra sih iya dia siapapun orangnya dia tetap rangkul kalau Bu T orangnya baik sekali. Saya bukan istilahnya di depan ade-ade ya emang kenyataan Bu T orangnya baik. Santunan juga iya sering hampir tiap tahun" (RJY, 54 Tahun)

\section{Wirausaha Sosial}

Karakteristik sociopreneur dalam aspek wirausaha sosial yang dimaksud dalam penelitian ini yaitu bagaimana seorang sociopreneur dapat melihat peluang untuk melakukan perubahan dan memenuhi kebutuhan sosial yang diciptakan untuk mengatasi masalah sosial. Karakteristik sociopreneur dalam aspek wirausaha sosial yang diamati dalam penelitian terdiri dari tiga komponen atau indikator, yaitu (1) menciptakan kegiatan atau usaha yang sesuai kemampuan masyarakat, (2) memberikan pelatihan khusus, (3) mengadakan kegiatan bisnis tour.

Tabel 9 Jumlah dan persentase persepsi responden terhadap karakteristik sociopreneur dalam aspek wirausaha sosial

\begin{tabular}{|c|c|c|}
\hline $\begin{array}{l}\text { Persepsi terhadap aspek wirausaha } \\
\text { sosial }\end{array}$ & Jumlah & $\begin{array}{l}\text { Persentas } \\
\mathrm{e}\end{array}$ \\
\hline Rendah & 0 & 0 \\
\hline \multirow[t]{2}{*}{ Sedang } & 2 & 63. \\
\hline & 1 & 6 \\
\hline \multirow[t]{2}{*}{ Tinggi } & 1 & 36. \\
\hline & 2 & 4 \\
\hline \multirow[t]{2}{*}{ Jumlah } & 3 & 10 \\
\hline & 3 & 0.0 \\
\hline
\end{tabular}

Persepsi responden terhadap karakteristik sociopreneur dalam aspek wirausaha sosial jika dilihat dari Tabel 13 termasuk ke dalam kategori sedang yaitu sebesar 63,6 persen. Dalam aspek wirausaha sosial, sociopreneur melihat peluang dalam mengatasi masalah sosial seperti 
pengangguran. Maka dari itu sociopreneur menciptakan kegiatan yang sesuai kemampuan dan minat dari masyarakat, ada yang di bidang kuliner, bidang desain, ada juga pengembangan sumber daya masyarakatnya seperti latihan public speaking. Beberapa orang yang telah mengikuti latihan public speaking, mereka menjadi percaya diri untuk berbicara di depan orang banyak, sehingga ketika ada kunjungan konsumen, mereka mampu menjelaskan secara garis besar terkait Kampung Wisata Bisnis Tegalwaru dan mereka sekaligus menjadi tour guide-nya. Selain itu, upaya yang dilakukan sociopreneur yaitu dengan mengadakan bisnis tour atau studi banding ke UMKM di luar Desa Tegalwaru. Hal tersebut dilakukan supaya para usaha UMKM yang ada di Desa Tegalwaru bisa belajar dan saling berbagi pengalaman dengan UMKM yang lain.

"Iya pernah ngajak bergabung, mempublikasikan kepada masyarakat disini, pernah ada juga pelatihan-pelatihan dari instansi yang lain. Terus bisa mengeksplornya lewat youtube, lewat website, jaringannya lebih luas." (GRR, 30 Tahun)

"Iya pernah mengunjungi yang sama-sama ukm ya, pernah saya ke jogja, tapi yang lain kayaknya belum sih. Selama saya sama Bu T baru ke jogja aja. Di jogja tuh, disana kita mengunjungi ukm-ukm juga disana, jadi studi banding kan, jadi kesana tuh kita ada ke ukm batik, disana kan banyak batik, tapi kalau untuk jamu nya engga begitu ya daerah sana, kalau jamu kayaknya lebih banyak ke solo, tapi itupun juga bukan, maksudnya bukan melewati ibu TK, jadi ibu udah dapet dari dinas untuk pelatihan, jalan sendiri, jadi ada undangan dari dinas ibu harus berangkat ke daerah ini sekian hari, ibu didanain sma pemerintah." (STH, 72 Tahun)

\section{Organisasi Kewirausahaan Sosial}

Karakteristik sociopreneur dalam aspek organisasi kewirausahaan sosial yang dimaksud dalam penelitian ini yaitu bagaimana seorang sociopreneur dapat menciptakan kegiatan untuk memberdayakan masyarakat atau komunitas-komunitas sosial sehingga mempunyai kemampuan dalam suatu bidang yang dapat memberikan manfaat terhadap masyarakat itu sendiri yang ditujukan untuk mencapai perubahan sosial. Karakteristik sociopreneur dalam aspek organisasi kewirausahaan sosial yang diamati dalam penelitian terdiri dari tiga komponen atau indikator, yaitu (1) menyelenggarakan acara latihan keterampilan, (2) memiliki keluangan waktu bersama untuk membicarakan hal-hal yang berkaitan dengan kewirausahaan sosial, (3) memberikan bantuan fasilitas kendaraan operasional.

Tabel 10 Jumlah dan persentase persepsi responden terhadap karakteristik sociopreneur dalam aspek organisasi kewirausahaan sosial

\begin{tabular}{lrr}
\hline $\begin{array}{l}\text { Persepsi terhadap aspek } \\
\text { organisasi kewirausahaan sosial }\end{array}$ & Jumlah & Persentase \\
\hline Rendah & 0 & 0 \\
Sedang & 15 & 45.5 \\
Tinggi & 18 & 54.5 \\
\hline Jumlah & 33 & 100.0 \\
\hline
\end{tabular}

Persepsi responden terhadap karakteristik sociopreneur dalam aspek organisasi kewirausahaan sosial jika dilihat pada tabel 14, termasuk ke dalam kategori tinggi yaitu sebesar 54,5 persen. Salah satunya yaitu menyelenggarakan acara ngabuburit kreatif yang dilaksanakan pada bulan suci Ramadhan. Kegiatan tersebut tidak hanya diisi dengan acara keagamaan seperti tausiyah dan mengaji bersama, tetapi juga dengan hal-hal positif lainnya seperti pemberian motivasi, latihan keterampilan, belajar bersama, dan lain sebagainya. Kemudian sociopreneur sebisa mungkin meluangkan waktu untuk berinteraksi dengan pemilik UMKM dan membicarakan hal-hal yang 
berkaitan dengan bisnis. Hal tersebut mampu membangun kedekatan antara sociopreneur dengan pemilik UMKM, sehingga dapat mengontrol tentang perkembangan suatu usaha yang dilakukan pemilik UMKM tersebut.

Selain itu, sociopreneur menyediakan fasilitas kendaraan operasional ketika ada kunjungan para konsumen. Konsumen yang datang biasanya rombongan dengan menggunakan kendaraan bus, tetapi untuk jalan menuju beberapa UMKM di Desa Tegalwaru dari UMKM satu ke UMKM yang lainnya cukup jauh dan tidak semuanya dapat dilewati oleh kendaraan besar, jadi untuk mengatasi hal tersebut disediakan kendaraan berupa odong-odong. Selain membantu para konsumen untuk menuju UMKM yang dituju, sopir dan pengelola odong-odong pun sangat terbantu sehingga mereka mendapat penghasilan.

"Ya acaranya belajar bareng, memberikan motivasi, kadang juga latihan keterampilan, tausiah, macem-macem ya namanya juga ngabuburit kreatif, biasanya sampai maghrib." (TK, 45 Tahun)

"Kegiatannya tentang kreativitas, latihan bikin kue, kerajinan tangan, dan lain-lain, seperti itu. Nanti mereka passion-nya dimana, nanti kita kasih modal, begitu. Pertemuannya rutin tiap minggu sekali. Mereka sekarang udah mandiri, udah produksi masing-masing di rumahnya. Sekarang mereka sedang meneruskan dengan skill mereka dengan dikasih modal, yaudah mereka bergulir mengerjakan produksi dan menjualnya, nanti bikin laporan." (RR, 42 Tahun)

\section{Orientasi Pasar}

Karakteristik sociopreneur dalam aspek orientasi pasar yang dimaksud dalam penelitian ini yaitu bagaimana seorang sociopreneur dapat mengembangkan suatu produk yang telah ada melalui kegiatan komersil dan keberlanjutan keuangan yang bertujuan untuk memberikan nilai positif atau menerapkan karakter kewirausahaan sosial seperti perilaku disiplin, inovatif, dan memiliki tekad kuat. Karakteristik sociopreneur dalam aspek orientasi pasar yang diamati dalam penelitian terdiri dari tiga komponen atau indikator, yaitu (1) cara dalam pengembangan produk, (2) melakukan pemasaran secara online, (3) memberikan bonus kepada UKM ketika ada kunjungan para konsumen.

Tabel 11 Jumlah dan persentase persepsi responden terhadap karakteristik sociopreneur dalam aspek orientasi pasar

\begin{tabular}{crr}
\hline Persepsi terhadap aspek orientasi & Jumlah & Persentase \\
pasar & 0 & 0 \\
Rendah & 7 & 21.2 \\
Sedang & 26 & 78.8 \\
Tinggi & 33 & 100.0 \\
\hline Jumlah & & \\
\hline
\end{tabular}

Tabel 15 menunjukkan bahwa persepsi responden terhadap karakteristik sociopreneur dalam aspek orientasi pasar termasuk ke dalam kategori tinggi yaitu sebesar 78,8 persen. Hal tersebut dapat dilihat dari bagaimana sociopreneur dalam mengembangkan atau mengenalkan produk dari hasil UMKM hingga dikenal oleh masyarakat luas, baik itu di dalam negeri maupun di luar negeri.

Sociopreneur dalam upaya mengenalkan UMKM di Desa Tegalwaru yaitu salah satunya dengan cara membuat website resmi supaya produk dari UMKM dan berbagai kegiatan yang dilakukan 
dapat diakses dan dilihat oleh masyarakat luas, kemudian juga menambahkan alamat masingmasing UMKM kedalam google maps supaya para konsumen maupun wisatawan tidak kesulitan dalam mencari tempat UMKM yang akan dikunjungi. Selain itu, promosi pun dilakukan di berbagai media, seperti media cetak, digital, dan juga televisi. Hal tersebut cukup berhasil karena mampu menarik konsumen dan wisatawan dari dalam negeri maupun luar negeri.

"Saya setelah adanya Kampung Wisata Bisnis Tegalwaru sangat terbantu, suatu wadah buat promosi keluar. Awal-awalnya membuat membuat, estelah selesai cari pasar sendiri, saya cari pasar mana yg bagus, sampai keluar jawa juga. Tapi setelah adanya Kampung Wisata Bisnis Tegalwaru saya ga pernah masarin lagi, tapi pesenan alhamdulillah banyak. Saya juga nanti kalau engga Januari atau Februari ke Jerman ke Berlin sama Universitas Indraprasta, difasilitasi sama kemenristekdikti. Kemarin juga dapat bantuan 158jt dari kemenristekdikti. Saya juga dibantu dipasarkan secara online, di google maps juga dibikinin, jadi orang-orang engga susah cari alamat." (RJY, 54 Tahun)

\section{Respon Pemilik UMKM terhadap Usaha-usaha yang dilakukan Sociopreneur}

Bab ini menjelaskan secara kualitatif bagaimana respon pemilik Usaha Mikro Kecil dan Menengah (UMKM) terhadap usaha-usaha yang dilakukan oleh sociopreneur. Bab sebelumnya menjelaskan secara kuantitatif bahwa persepsi pemilik UMKM terhadap karakteristik sociopreneur termasuk ke dalam kategori tinggi. Tetapi, menurut hasil penelitian beberapa persepsi dari pemilik UMKM tersebut ada yang menilai positif ada juga yang menilai negatif. Sehingga respon yang diberikan pemilik UMKM terhadap usaha-usaha yang dilakukan oleh sociopreneur pun ada yang positif ada pula yang negatif. Usaha yang dilakukan sociopreneur dalam mengembangkan UMKM di Desa Teglwaru yaitu 1) memberikan modal usaha ketika ada yang membutuhkan; 2) mendampingi UMKM dari sisi produk (rasa, produksi, branding, PIRT, pembukuan) supaya memiliki standarisasi yang baik; 3) mendampingi dari sisi pasar (mengenalkan pemasaran secara offline dan juga online); 4) mengadakan program sosial; dan 5) memberikan inovasi. Usaha-usaha yang dilakukan oleh seorang sociopreneur di Desa Tegalwaru juga dilakukan dengan usaha sebagaimana berjalan sesuai dengan karakteristik seorang sociopreneur. Karakteristik sociopreneur tersebut terdiri dari menciptakan nilai sosial, wirausaha sosial, organisasi kewirausahaan sosial, dan orientasi pasar.

Beberapa persepsi positif pemilik UMKM mengatakan bahwa hadirnya sociopreneur sangat mempengaruhi perkembangan produk usaha yang sedang dijalankan, juga terdapat perubahan ekonomi yang terjadi pada beberapa UMKM. Maka dari persepsi positif tersebut, respon positif yang diberikan oleh pemilik UMKM yaitu membuat mereka menjadi tanggap dan memanfaatkan kegiatan-kegiatan yang diselenggarakan oleh sociopreneur.

"Iya pernah ngajak bergabung, mempublikasikan kepada masyarakat disini, pernah ada juga pelatihan-pelatihan dari instansi yang lain. Terus bisa mengeksplornya lewat youtube, lewat website, jaringannya lebih luas." (GRR, 30 Tahun)

"Kalau sebelumnya itu (pendapatan) engga bisa dipastiin yaa, engga tentu, karena kadang-kadang saya nyari pasaran tuh susah banget. Kalo perbulannya dulu sebelum ada KWBT yaitu sekitar 2 jutaan, kalau sekarang dihitung rata-rata 5 jutaan ada juga lebih. Menurut duniawi orang engga ada puasnya, kita bersyukur aja, cukup ajalah berapapun kita dikasih rejeki." (RJY, 54 Tahun)

"Ketika tahun 2010 berdirilah Kampung Wisata Bisnis Tegal Waru yang bertujuan untuk menyatukan para industri rumahan dan memasarkannya. Hal tersebut mampu 
memancing orang luar untuk mengunjungi langsung dan membeli produk-produk yang ada di desa tersebut. Akhirnya Desa Tegal Waru yang awalnya merupakan desa tertinggal sekarang menjadi desa percontohan bagi desa lain.” (NN, 52 Tahun)

Hadirnya sociopreneur dalam mengembangkan Usaha Mikro Kecil dan Menengah (UMKM) di Desa Tegalwaru dengan menginisiasi berdirinya Kampung Wisata Bisnis Tegalwaru (KWBT) membawa dampak dan pengaruh positif terhadap perkembangan beberapa UMKM disana. Hal tersebut didukung dengan adanya pelatihan-pelatihan dari instansi terkait dan juga dari datangnya konsumen dan pengunjung ke UMKM yang ada di Desa Tegalwaru. Selain itu sociopreneur dapat mengenalkan produk-produk UMKM kepada masyarakat luas, tidak hanya di dalam negeri, tetapi sampai juga ke luar negeri. Berkembangnya UMKM di Desa Tegalwaru juga tidak terlepas dari usaha pemilik UMKM yang menerapkan hasil-hasil pengajaran dan pelatihan yang diajarkan oleh beberapa instansi yang diselenggarakan oleh sociopreneur.

"Dari instansi pemerintah pasti ada yang menawarkan, pelatihan produk-produk kayak gitu, salah satunya dari dinas pariwisata." (RR 42 Tahun)

"Ada juga yang ngasih pelatihan, itu YARSI, cara pemasaran dan pemberian label untuk seтиa UMKM, IPB juga pernah mengenai simpan pinjam.” (NN, 52 Tahun)

"Setelah adanya Kampung Wisata Bisnis Tegalwaru ya tentang pemasaran kebantu dengan datangnya tamu, dengan adanya tamu kan suka belanja, kadang kalau nol ya nol, kadang-kadang kalau ada tamu juga cuma tanya-tanya aja, ya engga ada bedanya sama kita jualan di pasar kan sama aja, kalau rame ya rame, kalau datang kebelutan gimana ya, banyak pembelinya sampai kita kadang kewalahan ngeladanginnya." (STH, 72 Tahun)

Tetapi, terdapat juga beberapa pemilik UMKM yang tidak merasakan dampak dari adanya sociopreneur, mereka merasa bahwa kehidupan sosial ekonomi mereka sama saja antara sebelum maupun sesudah adanya Kampung Wisata Bisnis Tegalwaru (KWBT). Hal tersebut dikarenakan beberapa faktor, salah satunya mereka jarang mengikuti kegiatan yang diselenggarakan oleh sociopreneur karena jarak tempat tinggal mereka cukup jauh dengan tempat diselenggarakannya acara tersebut. Kemudian ada juga responden yang mengatakan bahwa sociopreneur hanya cari untung sendiri dan hanya memanfaatkan UMKM yang ada di Desa Tegalwaru. Ada juga UMKM yang merasa terganggu dengan adanya pengunjung. Hal-hal seperti itulah yang membuat beberapa UMKM di Desa Tegalwaru kurang berkembang dengan baik.

"Awal-awal sih ada (yang tidak suka), mereka merasa terganggu dengan adanya keramaian, bagi yang berpikiran positif mereka akan postif juga. Tapi kalau bagi orang yang engga suka, apasih rame ganggu, banyak odong odong." (RR, 42 Tahun)

"Pertamanya nih dia bilang kalau ada kunjungan perorangnya bayar sepuluh ribu, pertama-pertamanya emang iya bener, terus kesana-kesananya cuma lima ribu, kadang ga dibayar, terus pengunjung datang kesini nih, kerena dia udah janji (akan dibayar) kita berharap dapet sepuluh ribu per orang, pertamanya doang, trerus akhirnya lama-lama engga. Kan pengunjung suka banyak kesini, puluhan, kadang malah riweuh, tapi kalau dibayar sih oke kan, kalau ga dibayar riweuh, kadang ada yang engga belanja, kalau ada yang belanja kan satu plus nilai buat kita krena buat oleh-oleh kan." (GRR, 30 Tahun)

"Ada yang engga suka dengan Kampung Wisata Bisnis Tegal Waru, cuma kita mah engga pernah dengerin, yaudah lanjut aja, ada yang dari warganya, karena mungkin 
mereka merasa terganggu dengan adanya tamu, karena kan tamu ada yg rese kan." (NH, 20 Tahun)

Penjelasan diatas menggambarkan persepsi positif maupun negatif pemilik UMKM terhadap sociopreneur. Persepsi pemilik UMKM tersebut mampu mempengaruhi respon terhadap usahausaha yang dilakukan sociopreneur.

Hal inilah yang menjadi penting dalam meneliti persepsi pemilik UMKM terhadap usaha-usaha yang dilakukan oleh sociopreneur. Bagaimana persepsi tersebut mampu memperngaruhi respon mereka dalam bertindak dan juga mempengaruhi keberhasilan dalam mengembangkan UMKMnya. Sehingga penting bagi sociopreneur dalam membangun persepsi positif terhadap pemilik UMKM yang ada di Desa Tegalwaru. Berhasil tidaknya pemberdayaan atau pengembangan UMKM yang dilakukan sociopreneur tersebut didukung oleh persepsi dan respon pemilik UMKM mengenai usaha-usaha yang dilakukan sociopreneur.

\section{Hubungan Kondisi Sosial Ekonomi Masyarakat Desa dengan Persepsi terhadap Karakteristik Sociopreneur}

Bab ini membahas mengenai sejauhmana hubungan antara kondisi sosial ekonomi pemilik Usaha Mikro Kecil dan Menegah (UMKM) dengan persepsi terhadap karakteristik sociopreneur di Desa Tegalwaru, Kecamatan Ciampea, Kabupaten Bogor. Pada bab sebelumnnya telah dijelaskan mengenai kondisi sosial ekonomi pemilik UMKM. Hasil pengukuran kuantitatif kondisi sosial ekonomi pemilik UMKM yang diklasifikasikan menjadi tingkat pendidikan, tingkat pendapatan, alat kepemilikan transportasi, dan pola interaksi sosial didapatkan bahwa dari keempat indikator sosial ekonomi tersebut menghasilkan tingkat pendapatan dan kepemilikan alat transportasi termasuk ke dalam kecenderungan tinggi. Sedangkan tingkat pendidikan dan pola interaksi mempunyai kecenderungan rendah. Pada bab persepsi terhadap karakteristik sociopreneur yang terdiri dari menciptakan nilai sosial, wirausaha sosial, organisasi kewirausahaan sosial, dan orientasi pasar didapatkan bahwa hasil pengukuran kuantitatif dari penilaian persepsi tersebut memiliki kecenderungan tinggi. Dengan hasil tersebut, maka dalam bab ini akan membahas mengenai pertanyaan pendukung yang meliputi: hubungan antara kondisi sosial ekonomi pemilik UMKM dengan persepsi terhadap karakteristik sociopreneur. Pertanyaan tersebut memunculkan hipotesis dalam penelitian ini, yakni adanya hubungan antara kondisi sosial ekonomi responden sebagai pemilik Usaha Mikro Kecil dan Menegah (UMKM) dengan persepsi terhadap karakteristik sociopreneur. Hipotesis pada penelitian ini dijawab dengan menganalisis menggunkan tabulasi silang dan diperkuat dengan uji korelasi Rank Spearman untuk skala ordinal sehingga dapat dilihat hubungan antara kondisi sosial ekonomi pemilik UMKM dengan persepsi terhadap karakteristik sociopreneur. Hubungan antara variabel tersebut dapat terlihat dari nilai koefisien korelasi.

\section{Hubungan Kondisi Sosial Ekonomi Masyarakat dengan Persepsi Terhadap Karakteristik Sociopreneur dalam Aspek Menciptakan Nilai Sosial}

Menciptakan nilai sosial merupakan salah satu karakteristik sociopreneur yang dapat berperan dalam memenuhi kebutuhan sosial dan mencapai tujuan sosial dengan kesetaraan dan toleransi. Kebutuhan dan tujuan sosial tersebut dapat dirasakan oleh masyarakat setelah adanya beberapa tindakan dari seorang sociopreneur dalam mengembangkan Usaha Mikro Kecil dan Menegah (UMKM) di Desa Tegalwaru. Sociopreneur mengajak masyarakat untuk bersama-sama dalam menjalankan misi sosial untuk kehidupan sosial ekonomi yang lebih baik. Jumlah dan persentase responden berdasarkan kondisi sosial ekonomi dengan persepsi terhadap karakteristik sociopreneur dalam aspek menciptakan nilai sosial padat dilihat pada Tabel 16. 
Tabel 12 Jumlah dan persentase responden berdasarkan kondisi sosial ekonomi dengan persepsi terhadap karakteristik sociopreneur dalam aspek menciptakan nilai sosial

\begin{tabular}{cccc}
\hline & \multicolumn{2}{c}{ Menciptakan Nilai Sosial } & Keterangan \\
\cline { 2 - 4 } $\begin{array}{c}\text { Kondisi Sosial } \\
\text { Ekonomi }\end{array}$ & $\begin{array}{c}\text { Koefisien } \\
\text { Korelasi }\end{array}$ & $\begin{array}{c}\text { Sig (2- } \\
\text { tailed) }\end{array}$ & \\
\cline { 2 - 4 } & $-0,155$ & 0,391 & $\begin{array}{c}\text { Sangat } \\
\text { Lemah }\end{array}$ \\
\hline
\end{tabular}

Kondisi sosial ekonomi pemilik UMKM dengan persepsi terhadap karakteristik sociopreneur dalam aspek menciptakan nilai sosial berdasarkan Tabel 16 menunjukkan hubungan yang sangat lemah. Hasil uji korelasi Rank Spearman antara kondisi sosial ekonomi pemilik UMKM dengan persepsi terhadap karakteristik sociopreneur dalam aspek menciptakan nilai sosial berdasarkan Tabel 22 dapat dilihat bahwa nilai koefisien korelasinya $-0,155$. Hal tersebut menunjukkan bahwa antara kondisi sosial ekonomi pemilik UMKM dengan persepsi terhadap karakteristik sociopreneur dalam aspek menciptakan nilai sosial memiliki hubungan yang sangat lemah. Selain itu, arah korelasi tersebut bernilai negatif yang artinya berlawanan arah. Artinya apabila semakin tinggi kondisi sosial ekonomi pemilik UMKM, maka tidak berhubungan dengan meningkatnya persepsi terhadap karakteristik sociopreneur dalam aspek menciptakan nilai sosial.

Ketika responden merasakan manfaat dari hadirnya sociopreneur dalam hal masalah sosial seperti pengangguran dan rendahnya pendidikan dapat sedikit teratasi. Walaupum kebermanfaatan tersebut tidak dirasakan oleh semua responden, tetapi hal tersebut dapat mengurangi jumlah pengangguran di Desa Tegalwaru. Kemudian beberapa responden menyatakan bahwa tingkat pendapatan mereka meningkat setelah bekerja sama dengan sociopreneur. Hadirnya sociopreneur membuat masyarakat memperoleh keuntungan baik dari segi ekonomi maupun sosial. Walaupun keuntungan yang dirasakan oleh setiap responden berbeda, akan tetapi keuntungan seperti berkembangnya produk UMKM merupakan keuntungan tersendiri bagi beberapa responden sebagai pemilik UMKM.

\section{Hubungan Kondisi Sosial Ekonomi Masyarakat Dengan Persepsi Terhadap Karakteristik Sociopreneur dalam Aspek Wirausaha Sosial}

Wirausaha sosial merupakan salah satu karakteristik sociopreneur yang dapat berperan dalam terciptanya perubahan sosial dan dilakukan untuk mengatasi masalah-masalah sosial. Masalah sosial yang dimaksud yaitu masalah pengangguran dan kemimkinan. Beberapa tindakan dari seorang sociopreneur dalam mengatasi masalah tersebut yaitu dengan menciptakan kegiatan atau suatu usaha sesuai dengan kemampuan masyarakat, dan juga memberikan pelatihan khusus agar usaha yang sedang dilaksanakan semakin pesat. Selain kegiatan tersebut, ada juga kegiatan bisnis tour bagi pelaku UMKM agar dapat belajar dari UMKM wilayah yang lain.

Tabel 13 Jumlah dan persentase responden berdasarkan kondisi sosial ekonomi dengan persepsi terhadap karakteristik sociopreneur dalam aspek wirausaha sosial

\begin{tabular}{cccc}
\hline & \multicolumn{2}{c}{ Wirausaha Sosial } & Keterangan \\
\cline { 2 - 3 } $\begin{array}{c}\text { Kondisi } \\
\text { Sosial } \\
\text { Ekonomi }\end{array}$ & $\begin{array}{c}\text { Koefisien } \\
\text { Korelasi }\end{array}$ & $\begin{array}{l}\text { Sig }(2- \\
\text { tailed) }\end{array}$ & \\
\cline { 2 - 3 } & $-0,224$ & 0,210 & $\begin{array}{c}\text { Sangat } \\
\text { Lemah }\end{array}$ \\
\hline
\end{tabular}

Kondisi sosial ekonomi responden dengan persepsi terhadap karakteristik sociopreneur dalam aspek wirausaha sosial berdasarkan Tabel 17 menunjukkan hubungan yang sangat lemah. Hasil uji korelasi Rank Spearman antara kondisi sosial ekonomi pemilik UMKM dengan persepsi 
terhadap karakteristik sociopreneur dalam aspek wirausaha sosial dapat dilihat dari nilai koefisien korelasi pada Tabel 17 yaitu sebesar $-0,224$. Hal tersebut menunjukkan bahwa antara kondisi sosial ekonomi pemilik UMKM dengan persepsi terhadap karakteristik sociopreneur dalam aspek wirausaha sosial memiliki hubungan yang lemah. Selain itu, arah korelasi tersebut bernilai negatif yang artinya berlawanan arah. Artinya apabila semakin tinggi kondisi sosial ekonomi pemilik UMKM, maka tidak berhubungan dengan meningkatnya persepsi terhadap karakteristik sociopreneur dalam aspek wirausaha sosial. Para pemilik UMKM mayoritas tidak merasakan manfaat dari aspek wirausaha sosial tersebut, karena banyak respon dari mereka yang mengatakan bahwa mereka kurang terlibat dari adanya beberapa kegiatan yang diselenggarakan oleh sociopreneur. Salah satu kegiatan tersebut yaitu adanya kegiatan bisnis tour supaya dapat belajar dan berbagi pengalaman dari UMKM di wilayah yang lain. Mayoritas responden mengatakan bahwa mereka tidak pernah mengikuti kegitan tersebut. Tetapi, ada juga kegiatan lain yang diselenggarakan oleh sociopreneur, yaitu kegiatan pelatihan khusus yang bekerja sama dengan beberapa instansi terkait, seperti pelatihan penjualan secara online, pembuatan P-IRT, kemasan yang menarik, dan lain sebagainya.

"Iya pernah ngajak bergabung, mempublikasikan kepada masyarakat disini, pernah ada juga pelatihan-pelatihan dari instansi yang lain. Terus bisa mengeksplornya lewat youtube, lewat website, jaringannya lebih luas." (GRR, 30 Tahun)

\section{Hubungan Kondisi Sosial Ekonomi Masyarakat Dengan Persepsi Terhadap Karakteristik Sociopreneur dalam Aspek Organisasi Kewirausahaan Sosial}

Organisasi kewirausahaan sosial dapat berupa komunitas sosial baik itu milik masyarakat atau swasta dalam sektor apapun yang ditujukan untuk mencapai perubahan sosial. Tindakan sociopreneur dalam mencapai perubahan sosial tersebut yaitu dengan beberapa cara seperti menyelenggarakan kegiatan latihan keterampilan, memiliki keluangan waktu bersama untuk membicarakan hal-hal yang berkaitan dengan bisnis, kemudian memberikan bantuan fasilitan kendaraan operasional untuk membantu UMKM.

Tabel 14 Jumlah dan persentase responden berdasarkan kondisi sosial ekonomi dengan persepsi terhadap karakteristik sociopreneur dalam aspek organisasi kewirausahaan sosial

\begin{tabular}{cccc}
\hline & \multicolumn{2}{c}{ Organisasi Kewirausahaan Sosial } & \\
\cline { 2 - 3 } Kondisi & Koefisien & Keterangan \\
Sosial & Korelasi & Sig & \\
Ekonomi & $-0,176$ & 0,327 & $\begin{array}{c}\text { Sangat } \\
\text { Lemah }\end{array}$ \\
\cline { 2 - 3 } & & & \\
\hline
\end{tabular}

Kondisi sosial ekonomi responden dengan persepsi terhadap karakteristik sociopreneur dalam aspek organisasi kewirausahaan sosial berdasarkan Tabel 18 menunjukkan hubungan yang sangat lemah antar kedua variabel tersebut. Hasil uji korelasi Rank Spearman antara kondisi sosial ekonomi pemilik UMKM dengan persepsi terhadap karakteristik sociopreneur dalam aspek organisasi kewirausahaan sosial dapat dilihat pada Tabel 28 bahwa nilai koefisien korelasinya sebesar -0,176. Hal tersebut menunjukkan bahwa antara kondisi sosial ekonomi pemilik UMKM dengan persepsi terhadap karakteristik sociopreneur dalam aspek organisasi kewirausahaan sosial memiliki hubungan yang sangat lemah. Selain itu, arah korelasi tersebut bernilai negatif yang artinya berlawanan arah. Artinya apabila semakin tinggi kondisi sosial ekonomi pemilik UMKM, maka tidak berhubungan dengan meningkatnya persepsi terhadap karakteristik sociopreneur dalam aspek organisasi kewirausahaan sosial. 


\section{Hubungan Kondisi Sosial Ekonomi Masyarakat Dengan Persepsi Terhadap Karakteristik Sociopreneur dalam Aspek Orientasi Pasar}

Orientasi pasar berkaitan dengan gagasan efisiensi tinggi dan efektivitas melalui kegiatan komersil dan keberlanjutan keuangan dan swasembada. Hal yang dilakukan oleh sociopreneur dalam aspek orientasi pasar yaitu dengan cara mengembangkan produk hasil dari UMKM yang ada di Desa Tegalwaru supaya dikenal oleh masyarakat luas, baik itu melalui media cetak, digital, dan juga televisi. Selain itu juga melakukan pemasaran secara online melalui akun media sosial seperti facebook, instagram, dan juga whatsapp.

Tabel 15 Jumlah dan persentase responden berdasarkan kondisi sosial ekonomi dengan persepsi terhadap karakteristik sociopreneur dalam aspek orientasi pasar

\begin{tabular}{cccc}
\hline & \multicolumn{3}{c}{ Orientasi Pasar } \\
\cline { 2 - 3 } $\begin{array}{c}\text { Kondisi Sosial } \\
\text { Ekonomi }\end{array}$ & $\begin{array}{c}\text { Koefisien } \\
\text { Korelasi }\end{array}$ & $\begin{array}{c}\text { Sig (2- } \\
\text { tailed) }\end{array}$ & Keterangan \\
\cline { 2 - 4 } & 0,093 & 0,391 & Lemah \\
\hline
\end{tabular}

Kondisi sosial ekonomi responden dengan persepsi terhadap karakteristik sociopreneur dalam aspek orientasi pasar berdasarkan pada Tabel 19 menunjukkan hubungan yang lemah. Hasil uji korelasi Rank Spearman antara kondisi sosial ekonomi pemilik UMKM dengan persepsi terhadap karakteristik sociopreneur dalam aspek orientasi pasar tersebut dapat dilihat pada Tabel 19 bahwa nilai koefisien korelasinya sebesar 0,093. Hal tersebut menunjukkan bahwa antara kondisi sosial ekonomi pemilik UMKM dengan persepsi terhadap karakteristik sociopreneur dalam aspek orientasi pasar memiliki hubungan yang sangat lemah. Tetapi, arah korelasi tersebut bernilai positif yang artinya searah. Artinya apabila semakin tinggi kondisi sosial ekonomi pemilik UMKM, maka berhubungan dengan meningkatnya persepsi terhadap karakteristik sociopreneur dalam aspek orientasi pasar.

Mayoritas responden menyatakan bahwa dengan adanya sociopreneur sangat bermanfaat bagi perkembangan UMKM mereka. Hal tersebut dibuktikan bahwa produk-produk dari UMKM yang ada di Desa Tegalwaru sudah dikenal oleh masyarakat luas, tidak hanya di dalam negeri tetapi juga sampai ke luar negeri. Sociopreneur mempromosikan dengan berbagai cara, salah satunya dengan melalui media sosial, sociopreneur juga memasarkan produk-produk UMKM tersebut secara online. Cara-cara yang dilakukan oleh sociopreneur tersebut mampu mengundang banyak konsumen maupun pengunjung yang datang ke Desa Tegalwaru untuk membeli produk atau belajar dari UMKM yang dikunjungi.

\section{KESIMPULAN}

Berdasarkan hasil penelitian mengenai Kondisi Sosial Ekonomi Pemilik Usaha Mikro Kecil dan Menengah (UMKM) dengan Persepsi terhadap Karakteristik Sociopreneur, dapat ditarik kesimpulan yaitu: Kondisi sosial ekonomi pemilik UMKM di Desa Tegalwaru, Kecamatan Ciampea, Kabupaten Bogor dalam penelitian ini termasuk ke dalam kategori tinggi. Dilihat dari tingkat pendapatan, mayoritas UMKM mendapatkan pendapatan diatas Upah Minimum Kabupaten Bogor 2020, yaitu sebesar Rp.4.083.670,00 perbulannya. Kemudian meskipun tingkat pendidikan pemilik UMKM mayoritas berada pada kategori rendah, tetapi tidak mempengaruhi mereka dalam menjalankan dan mengembangkan usahanya. Hal ini dikarenakan pemilik UMKM dapat belajar secara nonformal darimana saja seperti pelatihan-pelatihan yang diselenggarakan oleh beberapa instansi pemerintah, belajar dari kegiatan keterampilan yang diselenggarakan oleh sociopreneur, maupun belajar dari pengalaman dan juga dari UMKM yang lain. Para pemilik 
UMKM semuanya telah memiliki alat transportasi yang digunakan untuk menunjang ekonomi dan membantu aktivitas sehari-harinya: (1) Persepsi responden terhadap karakteristik sociopreneur dalam aspek menciptakan nilai sosial, wirausaha sosial, organisasi kewirausahaan sosial, dan orientasi pasar, semuanya termasuk ke dalam kategori tinggi. Hal tersebut membuktikan bahwa mayoritas pemilik Usaha Mikro Kecil dan Menengah (UMKM) yang ada di Desa Tegalwaru merasakan manfaat dari adanya sociopreneur dalam pengembangan UMKM di dalam program Kampung Wisata Bisnis Tegalwaru, terutama di dalam pemasaran sehingga produk-produk UMKM di Desa Tegalwaru sudah dikenal oleh masyarakat luas, tidak hanya di dalam negeri tetapi sampai juga ke luar negeri; dan (2) Kondisi sosial ekonomi pemilik UMKM dengan persepsi terhadap karakteristik sociopreneur terdapat hubungan yang tidak signifikan. Berdasarkan hasil lapang, hal ini disebakan karena adanya beberapa responden yang merasa bahwa kehidupan sosial ekonomi mereka sama saja antara sebelum maupun sesudah adanya sociopreneur. Hal tersebut dikarenakan beberapa faktor, salah satunya mereka jarang mengikuti kegiatan yang diselenggarakan oleh sociopreneur karena jarak tempat tinggal mereka cukup jauh dengan tempat diselenggarakannya acara tersebut. Kemudian ada juga responden yang mengatakan bahwa sociopreneur hanya cari untung sendiri dan hanya memanfaatkan UMKM yang ada di Desa Tegalwaru. Ada juga UMKM yang merasa terganggu dengan adanya pengunjung. Hal-hal seperti itulah yang membuat beberapa UMKM di Desa Tegalwaru kurang berkembang dengan baik.

\section{Saran}

Berdasarkan hasil penelitian yang telah dilakukan, maka terdapat beberapa saran yang dapat dijadikan masukan antara lain sebagai berikut: (1) Sociopreneur sebaiknya dapat membangun persepsi positif terhadap semua pemilik Usaha Mikro, Kecil, dan Menengah (UMKM) yang ada di Desa Tegalwaru sehingga persepsi tersebut mampu mempengaruhi respon pemilik UMKM secara positif terhadap usaha-usaha yang dilakukan sociopreneur; dan (2) Karakteristik sociopreneur dalam aspek menciptakan nilai sosial, wirausaha sosial, organisasi kewirausahaan sosial, dan orientasi pasar perlu ditingkatkan dan sebaiknya bisa terjangkau dan diikuti oleh seluruh pemilik UMKM di Desa Tegalwaru.

\section{DAFTAR PUSTAKA}

Anas MYA. 2019. Mengapa Sociopreneur Bukan Social Entrepreneur?. Jurnal Dialektika [internet]. [diunduh pada 2021 Jan 16]; 4 (2): 66-73.

Arifin Z. 2002. Kondisi Sosial Ekonomi Petani Tebu di Desa Negara Batin Sungkai Selatan [Skripsi]. Bandar Lampung [ID]: Universitas Lampung.

Arsyad L. 2003. Prospek Pengembangan Industri Kecil di Indonesia. Manajemen Usahawan Indonesia. Yogyakarta (ID): Sekolah Tinggi Ekonomi.

Bahrowi, Juariyah S. 2010. Analisa Kondisi Sosial Ekonomi dan Tingkat Pendidikan Masyarakat Desa Srigading Kecamatan Labuhan Maringgai, Kabupaten Lampung Timur. Jurnal Ekonomi dan Pendidikan [internet]. [diunduh pada 2019 Sept 17]; 07 (01): 58-81.

Baron RA, Byrne D. 2004. Psikologi Sosial Jilid 1. Edisi Kesepuluh. Djuwita R, Parman MM, Yasmina D, Lunanta LP, penerjemah; Kristiaji WC, Medya R, editor. Jakarta (ID): Erlangga. Terjemahan dari: Social Psychology 10th Edition. 307 hal.

[BPS] Badan Pusat Statistik. 2019. Profil Kemiskinan di Indonesia September 2018.

Effendi S. Tukiran. 2014. Metode Penelitian Survei. Jakarta (ID): LP3ES.

Erista AA. 2014. Dampak Industri terhadap Perubahan Sosial dan Ekonomi Masyarakat di Desa Tobat Kecamatan Balaraja Tangerang Banten [skripsi]. Jakarta (ID): UIN Syarif Hidayatullah.

Firdaus N. 2014. Pengentasan Kemiskinan Melalui Pendekatan Kewirausahaan Sosial. Jurnal Ekonomi dan Pembangunan [internet]. [diunduh pada 2021 jan 16]; 22 (1): 55-67. 
Garini CA. 2017. Pengaruh Status Sosial Ekonomi terhadap Adaptasi Mahasiswa Migran [skripsi]. Lampung (ID): Universitas Lampung.

Ghufronudin. 2018. Tindakan Sosial Pengusaha Kerajinan Logam dalam Mempertahankan Keberlangsungan Usaha. Dialektika Masyarakat: Jurnal Sosiologi [internet]. [diunduh pada 2019 Apr 18]; 02 (01): 13-23.

Haholongan H. 2016. Hubungan Implementasi Kebijakan Pembangunan dengan Pemberdayaan Masyarakat di Kecamatan Batununggal Kota Bandung [skripsi]. Bandung (ID): Universitas Pasundan.

Hartono, Hartomo DD. 2014. Faktor-faktor yang Mempengaruhi Perkembangan UMKM di Surakarta. Jurnal Bisnis dan Manajemen [internet]. [diunduh pada 2020 Apr 4]; 14 (01): 15-30.

Kurnianto BT. 2017. Dampak Sosial Ekonomi Masyarakat Akibat Pengembangan Lingkar Wilis di Kabupaten Tulungagung. Jurnal Agiribisnis Fakultas Pertanian [internet]. [diunduh pada 2019 Apr 4]; 13 (15): 55-85.

Lontoh LJV. 2016. Perubahan sosial ekonomi masyarakat nelayan di sekitar kawasan reklamasi di Kecamatan Sario Kota Manado. Jurnal Ilmiah Society. [Internet]. [diunduh pada 2019 Sept 15]; 2(20): 143-160.

Masturin. 2015. Model Pemberdayaanmasyarakat dengan Pendekatan Social Entrepreneurship: Analisis Ketokohan Para Pewirausaha Sosial. Inferensi Jurnal Penelitian Sosial Keagamaan [internet]. [diunduh 2019 Mar 3]; 09(01): 159-182.

Muryanti M. 2020. Menuju Kewirausahaan Sosial di Desa melalui Badan Usaha Milik Desa. Jurnal Society [internet]. [diunduh pada 2021 Jan 26]; 8 (01): 170-181.

Myers DG. 2012. Psikologi Sosial. Edisi ke-10. Tusyani A, Sembiring LS, Gaytri PG, Sofyan PN, penerjemah. Jakarta (ID): Penerbit Salemba Humanika. Terjemahan dari : Social Psychology.

Nasdian FT. 2015. Pengembangan Masyarakat. Jakarta [ID]: Yayasan Pustaka Obor Indonesia.

Prayogo C. 2017. Studi Deskriptif Social Entrepreneur Pada Pemilik Agfa di Sidoarjo, Jawa Timur, Indonesia. Jurnal Agora [internet]. [diunduh pada 2019 Mar 27]; 05 (01).

Putri LI. 2017. Reduksi Kemiskinan Melalui Sociopreneur. Jurnal Riset dan Kajian Keislaman [internet]. [diunduh 2019 Apr 24]; 06 (01): 48-68.

Rahman AA. 2013. Psikologi Sosial: Integrasi Pengetahuan Wahyu dan Pengetahuan Empirik. Depok (ID): PT Rajagrafindo Persada.

Ria IU. 2017. Pengaruh Keberadaan Industri Terhadap Kondisi Sosial Ekonomi Masyarakat di Desa Talaag Kecamatan Cikupa Kabupaten Tangerang [skripsi]. Jakarta (ID): UIN Syarif Hidayatullah.

Rusli Z, Sahuri C, Mashur D, Mayarni. 2011. Penerapan Social Enterpreneurship dalam Memberdayakan Masyarakat Miskin Perkotaan .Jurnal Kebijakan Publik [internet]. [diunduh pada 2019 Mar];

Salim A. 2018. Pengaruh Peran Sociopreneurship terhadap Keberhasilan Usaha. Jurrnal for Business and Entrepreneur [internet]. [diunduh pada 2020 Apr 24] 02 (02): 1-13.

Sarfiah SN, Atmaja HE, Verawati DM. 2019. UMKM sebagai Pilar Membangun Ekonomi Bangsa. Jurnal REP (Riset Ekonomi Pembangunan) [internet]. [diunduh 2020 Apr 24]; 04 (02): 137-146.

Sholikhatun UM. 2010. Hubungan Antara Karakteristik Sosial Ekonomi dengan Persepsi Masyarakat Kota tentang Sifat-sifat Inovasi Program Peningkatan dan Pengembangan Pertanian Perkotaan di Kota Surakarta [skripsi]. Surakarta (ID): Universitas Sebelas Maret.

Singarimbun, Effendi. 2014. Metode Penelitian Survei. Jakarta (ID): LP3ES.

Sjaf S. 2019. Involusi Republik Merdesa. Bogor (ID): IPB Press.

Sugiyono. 2013. Metode Penelitian Kombinasi (Mixed Methods). Bandung (ID): Penerbit Alfabeta. 
Sukmadi. 2016. Inovasi dan Kewirausahaan Edisi Paradigma Baru Kewirausahaan. Yogyakarta (ID): Pustaka Pelajar Grup.

Sukmawati AD. 2013. Deskripsi tentang Perkemabangan Sosial Ekonomi Masyarakat Desa Ratna Daya Kecamatan Raman Utara Kabupaten Lampung Timur [skripsi]. Lampung (ID): Universitas Lampung.

Sukirno S. 2011. Mikro Ekonomi Teori Pengantar Edisi Ketiga. Jakarta: Rajawali Pers.

Suyatna H, Nurhasanah Y. 2017. Sociopreneurship sebagai Tren Karir Anak Muda. Jurnal Studi Pemuda [internet]. [diunduh pada 2019 Mar 27]; 06(01): 527-537.

Tambunan T. 2002. Usaha Kecil dan Menengah di Indonesia: Beberapa Isu Penting. Jakarta (ID): Salemba Empat.

Taylor SE, Peplau LA, Sears DO. 2009. Psikologi Sosial. Wibowo T, penerjemah. Jakarta (ID): Kencana Prenada Media Grup. Terjemahan dari: Social Psychology edisi 12.

Thoha M. 2001. Perilaku Organisasi: Konsep Dasar dan Aplikasinya. Jakarta (ID): PT Raja Grafiindo Persada.

Trisanti T. 2001. Strategi Pemberdayaan Ekonomi Kerakyatan pada Saat Krisis Ekonomi. Manajemen Usahawan Indonesia. Yogyakarta (ID): Sekolah Tinggi Ekonomi.

[UU] Undang-Undang Republik Indonesia No. 20 Tahun 2008 Tentang Usaha Mikro, Kecil, dan Menengah.

[UU] Undang-Undang Nomor 20 tahun 2003 Tentang sistem Pendidikan Nasional.

Winarsih T. 2018. Analisis Sosial Ekonomi Masyarakat Sekitar Kawasan Berikat terhadap Motivasi Anak Melanjutkan Pendidikan Keperguruan Tinggi Menurut Perspektif Ekonomi Islam [skripsi]. Lampung (ID): UIN Raden Intan. 